\title{
Analisis Pengaruh Penerimaan Kekayaan Intelektual, Administrasi Hukum Umum dan Keimigrasian Terhadap Penerimaan Negara Bukan Pajak di Lingkungan Kementerian Hukum dan Ham RI
}

\author{
Sasmito $^{1}$, Anton Wahidin Widjaja ${ }^{2}$ \\ 1,2Program Studi Magister Manajemen Universitas Bhayangkara Jakarta Raya, \\ sasmito@yahoo.com
}

\begin{abstract}
ABSTRAK
Penelitian ini bertujuan untuk mengetahui dan menganalisis seberapa besar Penerimaan Negara Bukan Pajak yang diperoleh melalui kegiatan-kegiatan yang ada pada tingkat Kementerian Hukum dan HAM - RI. Jenis penelitian ini adalah deskriptif kuantitatif. Penentuan sampel diperoleh dari laporan keuangan Kementerian Hukum dan HAM RI selama periode 2009 sampai dengan 2014. Metode yang di pakai untuk menguji hipotesis ini adalah memakai uji regresi berganda (multiple regression). Data diolah melalui aplikasi program SPSS version 19.0 dengan menggunakan menu regression. Hasil penelitian ini menunjukkan bahwa Penerimaan Kekayaan Intelektual berpengaruh signifikan paling dominan terhadap Penerimaan Negara Bukan Pajak. Dimana Koefisien Penerimaan Kekayaan Intelektual sebesar 7,531, Berarti bahwa setiap peningkatan Penerimaan Kekayaan Intelektual sebesar 1\% maka akan mengakibatkan kenaikan Penerimaan Kekayaan Intelektual sebesar 7,531\%. Sedangkan koefisien Penerimaan Administrasi Hukum Umum hanya sebesar 1,317, yang berarti jika setiap peningkatan Penerimaan Administrasi Hukum sebesar 1\% maka akan mengakibatkan kenaikan PNBP entitas sebesar1,317\%. Dan yang paling kecil berdasarkan hasil SPSS yaitu Penerimaan Keimigrasian yang berarti bahwa setiap peningkatan Penerimaan Keimigrasian sebesar 1\% maka akan mengakibatkan kenaikan PNBP entitas sebesar 0,369\%. Berdasarkan hasil pengujian uji f, variable-variabel Penerimaan Kekayaan Intelektual, Penerimaan Administrasi Hukum Umum dan Penerimaan Keimigrasian secara bersama-sama berpengaruh signifikan terhadap Penerimaan Negara Bukan Pajak pada Kementerian Hukum dan HAM RI, karena nilai signifikannya sebesar 0,001 lebih kecil dari 0,05.

Kata Kunci: Penerimaan Negara Bukan Pajak, Administrasi Hukum Umum, Kekayaan Intelektual, Penerimaan Keimigrasian
\end{abstract}

\begin{abstract}
This study aims to find out and analyze how much Non-Tax State Revenues are obtained through activities that are at the level of the Ministry of Law and Human Rights - RI. This type of research is quantitative descriptive. Determination of samples was obtained from the financial statements of the Ministry of Law and Human Rights of the Republic of Indonesia during the period 2009 to 2014. The method used to test this hypothesis was using multiple regression tests. Data is processed through the application program SPSS version 19.0 using the regression menu. The results of this study indicate that Intellectual Property Revenue has the most dominant significant effect on Non-Tax State Revenues. Where the Coefficient of Intellectual Property Acceptance of 7.531, means that any increase in Intellectual Property Revenue of $1 \%$ will result in an increase in Intellectual Property Revenue of 7.531\%. Whereas the General Legal Administration Acceptance coefficient is only 1,317, which means that if every increase in Legal Administration Receipts is 1\%, it will result in an increase in the entity's PNBP of 1.317\%. And the smallest is based on the results of SPSS namely Immigration Receipt which means that every increase in Immigration Receipts by $1 \%$ will result in an increase in the entity's
\end{abstract}


PNBP of $0.369 \%$. Based on the results of $f$ test testing, the variables of Intellectual Property Acceptance, Acceptance of General Legal Administration and Immigration Acceptance together have a significant effect on Non-Tax State Revenues at the Ministry of Law and Human Rights, because the significant value is 0.001 smaller than 0.05 .

Keywords: Non-Tax State Revenue, General Law Administration, Intellectual Property, Immigration Receipts

Diterima: 2 Okt 2018; Direvisi: 20 Jan 2018; Diterbitkan: 15 April 2019

\section{PENDAHULUAN}

Penerimaan yang bersumber dari Pajak adalah penerimaan yang diperoleh dari regulasi/pengaturan Tata Usaha Pengelolaan Keuangan Negara karena keberadaan Negara sebagai sebuah State. Oleh karenanya penerimaan dari Pajak ini menurut hemat penulis seharusnya lebih kecil dari penerimaan obyek yang kena pajak itu sendiri. Obyek penerimaan negara bukan pajak yang ada di Republik Indonesia adalah bentangan kekayaan alam yang sangat luas dari Sabang sampai Merauke, meliputi beraneka ragam kegiatan manusia, meliputi sumber sumber kekayaan yang ada di seluruh wilayah Negara Kesatuan Republik Indonesia, di darat, di laut maupun dalam dasar bhumi, baik yang yang sudah terdata maupun masih bahan mentah, belum tergarap dan perawan.

Pada beberapa tahun terakhir asumsi penerimaan pajak menjadi dasar berpijak didalam penyusunan APBN. Target penerimaan pajak tahun 2014 adalah sebesar 1.000 triliun rupiah dan asumsi penerimaan pajak tahun 2015 kisaran 1.300 triliun lebih, sedangkan total APBN tahun 2014 kisaran 1.900 triliun. Sungguh luar biasa negeri tercinta Republik Indonesia ini, dari fakta penerimaan pajak saja sebagian besar biaya kebutuhan operasional Negara bisa dipenuhi dari sumber penerimaan pajak, artinya bahwa dari gambaran awal penerimaan pajak saja, regulasi pembiayaan Negara seharusnya tidak perlu mencari pinjaman hutang luar Negeri.

Penerimaan Negara Bukan Pajak disingkat PNBP seharusnya bukanlah suplemen dari penerimaan Negara, tetapi harus-lah menjadi inti dan tulang punggung dari seluruh penerimaan Negara. Kita tidak boleh hanya bersandar kepada penerimaan pajak yang kadang bisa naik dan bisa turun, atau kita tidak boleh juga mencari pinjaman luar negeri untuk membiayai kegiatan Negara yang dampaknya selalu dalam ketergantungan kepada pihak asing.

Penerimaan Negara Bukan Pajak, memiliki cakupan yang sangat luas, semua sumber penerimaan yang ada di seluruh teritorial Negara Kesatuan Republik Indonesia merupakan 'lahan galian' penerimaan negara bukan pajak. Potensi PNBP yang tersebar luas, didalam seluruh lini bentangan kekayaan alam yang tersimpan di bhumi pertiwi, baik yang masih mentah maupun dalam penguasaan perusahaan perusahaan multinasional harus digali oleh putra putri Indonesia sendiri dan dioptimalkan sebagai upaya menyejahterakan Bangsa ini.

Dengan kekayaan alam yang dimiliki negeri ini, seharusnya kita berusaha melepaskan dari jeratan hutang luar negeri, yang setiap tahun nilai hutang kita selalu membengkak terus, sampai dengan akhir Agustus 2015 saja negara kita memiliki hutang sebesar US\$ 304,28 miliar atau apabila di rupiahkan sebesar Rp. 4.260 triliun, dengan asumsi nilai tukar rupiah terhadap dollar sampai akhir Agustus 2015, 1 US \$ = Rp. 14.000, .sedangkan pada akhir Desember 2014 dengan jumlah hutang yang sama US\$ 304,28 miliar dengan nilai tukar rupiah saat itu terhadap dollar amerika 1 US\$ = Rp. 12.000,- hutang negara kita cuma Rp. 3.651 triliun, artinya dalam kurun relatif singkat, hanya 8 bulan hutang negara kita bertambah sebesar Rp.4.260 triliun - Rp. 3.651 triliun = Rp. 609 triliun.Pertambahan hutang tanpa diiringin hutang baru. 
Dilihat dari angka angka tersebut, Bangsa kita tidak berdaya dan menjadi mainan valuta asing seiring pasar dunia yang terus bergolak dan terus menanjak. Krisis seperti ini berulang kali terjadi di Republik Indonesia tercinta, akhir Pemerintahan Presiden Soekarno terjadi malaise, dimana terjadi degradasi rupiah sampai kemudian terjadi pemotongan rupiah ( sanering ) dari Rp.1000 menjadi Rp.1,- akhir Pemerintahan Presiden Soeharto pun nilai rupiah terhadap dollar merosot sampai dengan Rp.15.000,-/ 1 US dollar.Era Pemerintahan sekarang pun terjadi perubahann nilai tukar rupiah terhadap dollar amerika.

Presiden dengan dibantu seluruh rakyatnya, mengusahakan agar Kekayaan alam yang dimiliki Negeri ini menjadi sumber kemakmuran bagi rakyatnya dengan menggali seluruh potensi kekayaan alam, melakukan ekstensifikasi seluruh sumber penerimaan Negara, membuat kebijakan pro rakyat dengan melindungi rakyatnya dari perangkap dan jarahan pasar bebas dengan membuat peraturan yang mengedepankan kepentingan ekonomi rakyat menjadi kepentingan utama Negara.

Menjaga kepentingan rakyat, membuat peraturan yang melindungi segenap tumpah darah Indonesia, menjaga teritorial Negara dari keluar masuknya orang asing, mencatat dan mengesahkan badan hukum seluruh kegiatan yang ada dalam ruang lingkup Negara dan melindungi kekayaan intelektual Bangsa Indonesia serta menegakkan hukum dan melindungi hak asasi manusia, adalah bagian tugas utama Kementerian Hukum dan Ham Republik Indonesia.

Oleh karenanya penulis ingin mengupas dan mengurai permasalahan Penerimaan Negara Bukan Pajak yang ada pada Kementerian Hukum dan Hak Asasi Manusia - RI, dari segi urgensinya terhadap pelayanan masyarakat, dan pengaruhnya terhadap penganggaran Kementerian Hukum dan HAM - RI dan kontribusinya terhadap Negara. Kementerian Hukum dan HAM-RI sejak awal berdiri Negara bernama Kementerian Kehakiman - RI, memiliki sejarah yang sangat luar biasa.Dengan menteri pertamanya Mr. Soepomo, dimana terkenal dengan karya yang sangat monumental berupa tafsir penjelasan UUD 1945 dan telaahan tentang pemerintahan sistem Kabinet Presidentil maupun sistem Kabinet Parlementer. Penerimaan Kekayaan Intelektual, penerimaan Administrasi Hukum Umum dan penerimaan Keimigrasian sebagai penerimaan yang cukup signifikan dan sangat mempengaruhi terhadap Penerimaan Negara Bukan Pajak pada Kementerian Hukum dan HAM - RI, dan cenderung meningkat dari tahun ketahun. Penerimaaan lainnya yang terdiri dari penerimaan Itjen, Setjen, Ditjen PP, Ditjen HAM, Balitbang HAM, BPSDM, BPHN dan Ditjen Pas cenderung konstan dan tetap dari tahun ke tahun serta memiliki nominal jumlah yang relative kecil dibandingkan penerimaan dari Kekayaan Intelektual, Administrasi Hukum Umum dan Keimigrasian.

Penerimaan dari Jasa Tenaga Narapidana yang diperoleh oleh Direktorat Jenderal Pemasyarakatan cenderung meningkat drastis karena perubahan restrukturisasi program anggaran yang semula RUTAN dan LAPAS dibawah kendali Sekretariat Jenderal kemudian berubah dibawah Direktorat Jenderal Pemasyarakatan, namun demikian penerimaan jasa tenaga narapidana relative sangat kecil dibandingkan Penerimaan Negara Bukan Pajak secara keseluruhan pada Kementerian Hukum dan HAM - RI.

Dilain pihak, penerimaan jasa tenaga narapidana tidak seharusnya dijadikan sebagai dasar acuan penerimaan negara bukan pajak, karena akan terkesan adanya exploitasi terhadap warga binaan, menghindari justifikasi oleh pihak pihak yang tidak bertanggung jawab seperti organisasi internasional (amnesty internsional, Komnas HAM, dll) terhadap Kementerian Hukum dan HAM dengan label/cap perbudakan terhadap narapidana, dan sudah seharusnya penerimaan yang diperoleh warga binaan/narapidana melalui kerja secara sukarela dikembalikan seratus persen kepada warga binaan sebagai upaya pembinaan pihak negara kepada narapidana, tanpa se - rupiah pun institusi negara memungutnya.

Selanjutnya dalam penelitian ini penulis akan menfokuskan kepada penerimaan Kekayaan Intelektual, penerimaan Administrasi Hukum Umum dan penerimaan Keimigrasian 
sebagai variable dalam penelitian, sedangkan yang tergabung dalam penerimaan lainnya ( penerimaan itjen, setjen, ditjen pp, ditjen ham, bphn, bpsdm, balitbang ham dan ditjen pas ) tidak masuk dalam kategori variable yang di akan diteliti, namun demikian khusus penerimaan jasa tenaga narapidana akan dimasukkan temuan peneliti sebagai bagian kesimpulan dan saran dalam upaya perbaikan paradigma Kementerian Hukum dan HAM - RI dimasa masa yang akan datang.

Gambaran diatas, memberikan kondisi pasti bahwa tugas pokok yang di emban Kementerian Hukum dan HAM - RI sangat komplek karena menyangkut kelangsungan kehidupan berbangsa dan bernegara, sehingga memerlukan pembiayaan dan pengganggaran yang memadai dan mampu menjangkau seluruh aspek didalam dalam tata kelola pemerintahan dalam Negara Kesatuan Republik Indonesia.

Seperti kita ketahui, sistem penganggaran kita menganut sistem penganggaran yang berimbang, artinya apa? Artinya budget anggaran yang di dapat dari penerimaan negara itulah yang akan dikeluarkan sebagai pembiayaan negara dalam tahun anggaran berjalan. Apabila target penerimaan negara tidak tercapai maka akan dilakukan pemangkasan disesuaikan dengan kondisi capaian anggaran pada saat tahun berjalan, akibatnya banyak kegiatan yang sudah di programkan tidak dapat dilaksanakan. Keberadaan Penerimaan Negara Bukan Pajak Kementerian Hukum dan HAM - RI, dilihat perolehan dari tahun ke tahun memiliki nilai yang cukup berarti apabila dibandingkan dari total keseluruhan penganggaran di tingkat Kementerian. Penerimaan Negara Bukan Pajak yang melekat pada Kementerian Hukum dan HAM menjadi tumpuan dan harapan besar bagi terselenggaranya tata kelola pemerintahan, terutama unit unit penghasil PNBP maupun unit eselon I lainnya dalam satu Kementerian.

Fungsi PNBP Kementerian menjadi sangat penting didalam upaya menjaga stabilitas penganggaran tahun berjalan. PNBP menjadi berdaya guna dan mampu menjadi suplemen penganggaran disaat target penerimaan Negara dari sumber sumber lain tidak tercapai.
PNBP Kementerian Hukum dan HAM RI, diharapkan mampu menjawab kebutuhan kebutuhan operasional dilapangan karena PNBP memiliki fungsi seperti:

1. Budgeting, fungsi penganggaran dari PNBP menjadi lebih dominan apabila target asumsi penerimaan negara tidak tercapai, maka melalui ijin penggunaan PNBP bisa menutupi kekurangan yang mungkin timbul akibat penerimaan negara dari sumber penerimaan pajak tidak tercapai. sehingga budget cyclus bisa berjalan normal.

2. Regulatory, fungsi pengaturan pelayanan terhadap masyarakat menjadi lebih optimal, karena ketersediaan dana.Persoalan persoalan hambatan di lapangan lebih mudah diatasi dengan ijin penggunaan dana PNBP dari satuan kerja bersangkutan.

Banyak hal yang harus dilakukan terkait fungsi regulatory dari PNBP ini,terutama sekali perubahan terhadap UU PNBP supaya lebih fleksibel, dimana ijin penggunaan lebih memiliki daya jangkau, mudah dalam implementasi, dan mampu memberdayakan Kementerian menjadi lebih tangguh.

Undang - Undang Nomor 20 Tahun 1997 tentang penerimaan negara bukan pajak adalah saat pertama Negara memiliki alas hukum untuk melakukan penataan dan inventarisasi penerimaan negara yang berasal dari bukan pajak. Berdasar atas Undang Undang ini pulalah, Negara melakukan pencatatan dan pembukuan secara teratur sumber sumber penerimaan negara bukan pajak untuk pembiayaan kegiatan Negara. PNBP pada Kementerian Hukum dan HAM - RI, merupakan bagian dari Penerimaan Negara Bukan Pajak (PNBP) secara nasional, dan merupakan bagian integral dari sistem mekanisme penganggaran yang ada pada saat sekarang.

Undang -undang No. 20 Tahun 1997 Pasal 2 ayat, sub item d. menerangkan bahwa : "Penerimaan dari Kegiatan layanan yang dilaksanakan oleh Pemerintah", artinya bahwa penerimaaan layanan yang dilakukan oleh Kementerian Hukum dan HAM - RI, adalah bagian dari Penerimaan Negara Bukan Pajak. 
Pada Kementerian Hukum dan HAM - RI, terdapat beberapa kegiatan yang merupakan bentuk layanan kepada masyarakat, dan dari layanan tersebut Kementerian Hukum dan HAM - RI memperoleh jasa pungut untuk setiap kali memberikan layanan. Bentuk - bentuk layanan yang diberikan instistusi ini semuanya merupakan produk hukum, perijinan, surat/ pas keluar masuk negara. Layanan - layanan ini sangat berkait dengan legitimasi hukum dari pemohon layanan, dan ini sesuai dari tugas pokok Kementerian Hukum dan HAM - RI.

Selanjutnya pengelolaan anggaran yang bersumber dari PNBP merupakan salah satu kegiatan administrasi utama dalam kepemerintahan yang menuntut prinsip tata kelola yang baik dan mengharuskan setiap organisasi melakukan pelaksanaan anggaran dengan baik dan benar, sehingga setiap kegiatan dapat dipertanggungjawabkan secara transparan dan akuntabel.

Managemen pengelolaan anggaran yang cepat, tepat dan akurat, salah satu upaya besar Kementerian Hukum dan HAM - RI, sehingga dapat dilakukan deteksi dini terhadap realisasi penerimaan negara bukan pajak dan deteksi dini terhadap penyerapan anggaran tahun berjalan, sehingga persoalan terkait dengan memiliki skala organisasi yang besar, sebaran geografis yang luas dan kewenangan perbendaharaan yang terdesentralisasi dengan jumlah kantor/satuan kerja diatas 813 satuan kerja, yang tersebar di seluruh pelosok Indonesia akan mudah diatasi dan mudah ditanggulangi. pentingnya penggunaan e-riil pnbp kemenkumham, dan e-serap anggaran kumham.

Dengan kata lain apabila data tersaji dengan cepat, tepat dan akurat maka bisa dilakukan penyusunan program yang lebih feasible, mudah dicerna mudah dipertanggungjawabkan. Dalam rangka mendukung terwujudnya kepemerintahan yang baik (good governance) dalam penyelenggaraan negara, pengelolaan keuangan negara perlu diselenggarakan secara profesional terbuka dan bertanggung jawab sesuai dengan aturan pokok yang telah di tetapkan dalam Undang-Undang Dasar Negara RI tahun 1945.

\section{KAJIAN TEORETIK}

\section{Penerimaan Pajak}

Menurut Adrian Sutedi (2011), pajak bisa diartikan sebagai berikut: "Hak untuk mencari memperoleh penghasilan sebanyak banyaknya membawa kewajiban menyerahkan sebagian kepada Negara dalam bentuk pajak, begitu pula hak untuk memiliki properti, baik gedung, mobil dan barang lain membawa konsekwensi kewajiban membayar pajak untuk properti dan barang yang dimilikinya. Definisi tentang pajak ini bisa dikutip dari beberapa ahli yang menjadi rujukan para ilmuwan sebagai berikut :

1. PJA Adriani (Guru Besar pada Universitas Amsterdam Netherland), beliau memberikan definisi sebagai berikut: "Pajak adalah iuran pada Negara yang dapat dipaksakan, yang terutang oleh yang wajib membayarnya menurut peraturan - peraturan dengan tidak dapat prestasi kembali, yang langsung dapat ditunjuk, dan yang gunanya untuk membiayai pengeluaran - pengeluaran umum berhubungan dengan tugas pemerintah".

2. Soeparman Soemahamidjaya, dalam desartasinya yang berjudul "Pajak Berdasarkan Asas Gotong Royong", memberikan definisi sebagai berikut: Pajak adalah iuran wajib, berupa uang atau barang yang dipungut oleh penguasa berdasarkan norma norma hukum guna menutup biaya produksi barang barang atau jasa jasa kolektif dalam mencapai kesejahteraan umum. Kemudian beliau mendefinisikan secara singkat bahwa "Pajak adalah iuran wajib yang dalam pelaksanaannya dapat dipaksakan kepada wajib pajak".

3. Rochmat Sumitro, memberikan definisi lebih tegas dan lugas yaitu, "Pajak adalah iuran rakyat kepada Negara berdasarkan Undang Undang (dapat dipaksakan), dengan tidak mendapatkan jasa timbal balik yang dapat ditunjuk langsung dan digunakan untuk membiayai pembangunan". 
Penerimaan Negara Bukan Pajak.

Menurut Muhammad Djafar Saidi, SH.MH (2011), sumber keuangan negara dalam bentuk pendapatan setiap saat dapat mengalami perubahan, baik dalam bentuk jenis pendapatan negara maupun dalam bentuk pengurangan jenis penerimaan negara, ketika terjadi penambahan ataupun pengurangan jenis pendapatan negara wajib diatur dengan undang undang sebagai konsekwensi dari negara hukum.

Terkait dengan hal tersebut mencari rujukan tentang definisi Penerimaan Negara Bukan Pajak, belum ada ahli dan ilmuwan yang membuat definisi secara khusus, kecuali pengertian secara leksikal dan lugas dari kosa kata " Penerimaan Negara Bukan Pajak, yang bisa diartikan sebagai penerimaan Negara yang berasal dari apa saja yang didapat dari pengelolaan Negara yang ada diseluruh persada tanah air, yang tersembunyi mapun yang terang terangan sebagai bagian tak terpisahkan dari Negara Kesatuan Republik Indonesia, diluar regulasi penerimaan pajak Negara".

Bertitik tolak dari makna kosa kata 'Penerimaan Negara Bukan Pajak', itu sendiri maka pasal 33 Undang Undang Dasar 1945 menjadi alas alas hak yang pas untuk membuat definisi tentang penerimaan negara bukan pajak, ayat 2 dan 3 bagian integral dari upaya optimalisasi PNBP. UUD 1945, Pasal 33 ayat (2) dan (3) sangat bermakna didalam membuat tafsir penerimaan Negara Bukan Pajak. Ayat 2 menyampaikan 'Cabang - cabang produksi yang menguasai hajat hidup orang banyak dikuasai Negara'. Ayat 3 menyampaikan 'Bhumi, Air dan Kekayaan alam yang terkandung didalamnya dikuasai Negara untuk dipergunakan sebesar besarnya kemakmuran rakyat'. Makna secara harfiah berdasarkan hukum tertulis bisa kita ditemukan di UU PNBP Nomor 20 Tahun 1997 pasal 2 yaitu : penerimaan pemerintah pusat yang tidak berasal dari penerimaan perpajakan.

Undang - Undang ini lahir tatkala reformasi bergulir pasca Pemerintahan Presiden Soeharto, tiga pejabat Pemerintahan saat itu sangat concern terhadap lahirnya UU ini, yaitu Presiden BJ Habibie, Menteri Kehakiman RI, Muladi dan Menteri Keuangan Bambang
Sudibyo, berupaya keras agar rakyat mendapatkan sumber pembiayaan Negara dari penerimaan Negara Bukan Pajak yang terang terangan sangat diamanatkan dalam UUD 1945. Oleh karenanya dengan kesigapan Trio Pejabat Negara saat itu lahir - lah Undang Undang Nomor 20 Tahun 1997 tentang Penerimaan Negara Bukan Pajak.

Pasal 2 Undang-Undang Nomor 20

Tahun 1997 tentang Penerimaan Negara Bukan Pajak (PNBP) kelompok penerimaan negara bukan pajak meliputi :

1. Penerimaan yang bersumber dari pengelolaan dana pemerintah seperti penerimaan jasa giro dan penerimaan sisa anggaran tahun anggaran yang lalu;

2. Penerimaan dari pemanfaatan sumber daya alam seperti penerimaan royalti dari sektor kehutanan, pertambangan dan perikanan;

3. Penerimaan dari hasil-hasil pengelolaan kekayaan negara yang dipisahkan berupa penerimaan dari deviden dan hasil penjualan saham pemerintah;

4. Penerimaan dari kegiatan pelayanan yang dilaksanakan pemerintah seperti pemberian hak atas kekayaan intelektual, pemberian paspor dan pelayanan jasa pendirian badan hukum;

5. Penerimaan berdasarkan putusan pengadilan dan yang berasal dari pengenaan denda administrasi seperti penerimaan lelang, barang rampasan dan denda;

6. Penerimaan berupa hibah yang merupakan hak pemerintah; dan

7. Penerimaan lainnya yang diatur dalam undang-undang tersendiri.

\section{Jenis dan Tarif Penerimaan Negara Bukan Pajak.}

Jenis dan tarif penerimaan negara bukan pajak ditetapkan oleh Peraturan Pemerintah atas usul dari Kementerian/Lembaga terkait. Pemungutan satuan biaya PNBP ditetapkan setelah Peraturan Pemerintah yang mengatur tentanng jenis dan tarif PNBP sudah ditandatangani. Apabila satuan biaya yang baru belum ada maka institusi Kementerian/Lembaga menggunakan Peraturan Pemerintah yang lama 
sebagai acuan penentuan pemungutan tarif PNBP.

Peraturan Pemerintah Nomor 45 tahun 2014 mengatur tentang tatacara penentuan jumlah pembayaran dan penyetoran Penerimaan Negara Bukan Pajak (PNBP) yang terutang. Peraturan Pemerintah tentang Jenis setiap instansi Kementerian/Lembaga berbeda beda, khusus untuk Kementerian Hukum dan HAM diatur melalui PP nomor 45 Tahun 2014 tentang Tarif atas Jenis Penerimaan Negara Bukan Pajak yang berlaku pada Kementerian Hukum dan HAM.

Tarif atas jenis Penerimaan Negara Bukan Pajak ditetapkan dengan memperhatikan dampak pengenaan terhadap masyarakat dan kegiatan usahanya, biaya penyelenggaraan kegiatan pemerintahan sehubungan dengan jenis Penerimaan Negara Bukan Pajak yang bersangkutan dan aspek keadilan dan pengenaan beban kepada masyarakat. Oleh karena itu, penetapan tarif atas jenis Penerimaan Negara Bukan Pajak merupakan pertimbangan secermat mungkin agar pembebanannya kepada masyarakat wajar dan memberikan kemungkinan perolehan keuntungan dan tidak menghambat kegiatan usaha yang dilakukan oleh dunia usaha.

Pengusulan perubahan jenis dan tarif atas jenis Penerimaan Negara Bukan Pajak pada Kementerian Hukum dan HAM dikoordinir oleh Sekretariat Jenderal dengan mempertimbangkan aspek-aspek tersebut di atas. Sekretaria Jenderal menampung dan memproses usulan perubahan/ penambahan jenis dan tarif atas jenis Penerimaan Negara Bukan Pajak yang diusulkan Unit Eselon I. Usulan perubahan/penambahan kenaikan tarif atas jenis Penerimaan Negara Bukan Pajak tersebut telah disosialisasikan oleh Unit-unit terkait kepada semua stake holder, sehingga dapat diminimalisir timbulnya keberatan di kemudian hari pada saat jenis dan tarif Penerimaan Negara Bukan Pajak tersebut diberlakukan.

Seluruh Penerimaan Negara Bukan Pajak yang diterima oleh Satuan Kerja/ Unit Pelaksana Teknis wajib langsung disetor ke Kas Negara sesuai amanat Peraturan Pemerintah Nomor 22 Tahun 1997 tentang Jenis dan Penyetoran Penerimaan Negara Bukan Pajak. Penerimaan tersebut disetor ke kas negara oleh Bendahara Penerimaan dengan formulir Surat Setoran Bukan Pajak (SSBP).

Satuan Kerja yang memungut PNBP wajib menyampaikan laporan rencana dan realisasi penerimaan secara periodik sesuai dengan Peraturan Pemerintah Nomor 1 Tahun 2004 tentang Tata Cara Penyampaian Rencana dan Laporan Realisasi Penerimaan Negara Bukan Pajak. Laporan realisasi PNBP wajib dilaporkan kepada Menteri Keuangan dalam bentuk Laporan Realisasi PNBP Triwulan yang disampaikan paling lambat 1 (satu) bulan.

Pada dasarnya seluruh PNBP wajib disetor langsung secepatnya ke kas negara. Namun demikian, untuk beberapa kegiatan tertentu, sebagian dana dari suatu jenis Penerimaan Negara Bukan Pajak dapat digunakan untuk kegiatan tertentu oleh instansi yang bersangkutan. Tata cara penggunaan Penerimaan Negara Bukan Pajak sebagaimana diatur dalam Peraturan Pemerintah Nomor 73 Tahun 1999 tentang Tata Cara Penggunaan Penerimaan Negara Bukan Pajak Yang Bersumber dari Kegiatan Tertentu, antara lain menyebutkan bahwa instansi dapat menggunaan sebagian dana Penerimaan Negara Bukan Pajak setelah memperoleh persetujuan Menteri Keuangan. Adapun kegiatan yang dapat menggunakan sebagian dana PNBP tersebut meliputi:

1. Penelitian dan pengembangan teknologi;

2. Pelayanan kesehatan;

3. Pendidikan dan Pelatihan;

4. Penegakan Hukum;

5. Pelayanan yang melibatkan kemampuan intelektual tertentu;

6. Pelestarian sumber daya alam.

Instansi pemerintah yang sudah mendapatkan persetujuan penggunaan dana Penerimaan Negara Bukan Pajak mengajukan rencana penggunaan (termasuk perubahan target penerimaan dan penggunaan) dana Penerimaan Negara Bukan Pajak kepada Menteri Keuangan. Rencana penggunaan dana Penerimaan Negara Bukan Pajak tersebut diteliti dan dibahas oleh Kementerian Keuangan bersama instansi pemerintah yang bersangkutan sebelum ditetapkan oleh Menteri Keuangan. Ketentuan ini dimaksudkan sebagai salah satu 
upaya untuk meningkatkan kualitas kegiatan pelayanan pemerintah, peningkatan ladlizas sumber daya manusia, menunjang kegiatan penelitian dan pengembangan teknologi dan meningkatkan pengelolaan sumber daya alam secara berkelanjutan.

\section{Penerimaan Negara Bukan Pajak pada Kementerian Hukum dan HAM - RI.}

Pasal 2 UU Nomor 20 Tahun 1997 huruf d. salah satu point yang terkait dengan sumber Penerimaan Negara Bukan Pajak(PNBP) adalah, "Kegiatan Layanan yang dilakukan oleh Pemerintahan". Kegiatan layanan inilah yang menjadi satu pokok bahasan dalam penulisan tesis ini. Kegiatan layanan Pemerintah yang dilaksanakan Kementerian Hukum dan Ham cukup banyak dan variable, dan hampir seluruh unit eselon I memiliki sumber penerimaan negara bukan pajak.

Jenis-jenis layanan dan merupakan penerimaan Negara Bukan Pajak meliputi penerimaan dari layanan:

1. Pelayanan Hak Kekayaan Intelektual

2. Pelayanan Jasa Hukum dan Harta Peninggalan.

3. Pelayanan Keimigrasian.

4. Pelayanan Pendidikan dan Pelatihan.

5. Pelayanan Kerjasama dengan Pihak Ketiga atas Jasa Tenaga Narapidana dalam rangka pembinaan kemandirian.

6. Pelayanan Kesehatan Rumah Sakit Pengayoman Cipinang.

Tiga dari layanan Kementerian Hukum dan HAM - RI, memiliki potensi penerimaan yang cukup signifikan dan terus mengalami kenaikan dari tahun ke tahun yaitu:

1. Layanan Hak Kekayaan Intelektual oleh Direktorat Jenderal Kekayaan Intelektual.

2. Layanan Jasa Hukum oleh Direktorat Jenderal Administrasi Hukum Umum, Divisi Pelayanan Hukum Kanwil KemenkumHAM RI di Ibukota Propinsi, dan Satuan Kerja Balai Harta Peninggalan Jakarta, Semarang, Surabaya, Medan dan Makkasar.

3. Layanan Keimigrasian oleh Direktorat Jenderal Imigrasi dan Unit Satker Imigrasi yang tersebar di seluruh pelosok tanah Air.

\section{Hak Kekayaan Intelektual.}

HKI atau juga dikenal dengan HAKI merupakan terjemahan atas istilah Intellectual Property Right (IPR). Istilah tersebut terdiri dari tiga kata kunci, yaitu Hak, Kekayaan, dan Intelektual. Kekayaan merupakan abstraksi yang dapat dimiliki, dialihkan, dibeli, maupun dijual. Adapun Kekayaan Intelektual merupakan kekayaan atas segala hasil produksi kecerdasan daya pikir seperti teknologi, pengetahuan, seni, sastra, gubahan lagu, karya tulis, karikatur, dan seterusnya. Terakhir, Hak atas Kekayaan Intelektual (HAKI) merupakan hak-hak (wewenang/kekuasaan) untuk berbuat sesuatu atas kekayaan intelektual tersebut, yang diatur oleh norma-norma atau hukum hukum yang berlaku.

Prof. Mahadi ketika menulis buku tentang Hak Milik Immateril "Property Right (Hak Kekayaan Intelektual)”, dapat disimpulkan bahwa Hak Kekayaan Intelektual itu adalah hak kebendaan, hak atas sesuatu benda yang bersumber dari kerja otak, hasil kerja ratio. Hasil kerja pekerjaan manusia yang nalar. Hasil kerjanya itu berupa benda immateril. Benda tidak berwujud. Kita ambil contoh misalnya karya sebuah lagu, untuk menciptakan alunan nada (irama) diperlukan pekerjaan otak. Menurut ahli biologi otak kanan-lah yang berperan untuk menghayati kesenian, berkhayal, menghayati kerohanian, termasuk juga kemampuan melakukan sosialisasi dan mngendalikan emosi. Fungsi ini disebut sebagai fungsi non ferbal, metaforik, intuitif, imaginatif dan emosional. Spesialisasinya bersifat intuitif, holistic, dan mampu memproses informasi secara simultan.

Hasil kerja otak itu kemudian dirumuskan sebagai intelektualitas. Orang yang optimal memerankan kerja otaknya disebut sebagai orang yang terpelajar, mampu menggunakan ratio, mampu berpikir secara rasional dengan menggunakan logika (metode berfikir, cabang filsafat), karena itu hasil pemikirannya disebut rasional dan logis. Orang yang tergabung dalam kelompok ini disebut kaum Intelektual. 
Demikian juga hasil kerja otak (intelektualitas) dalam bentuk penelitian atau temuan dalam bidang teknologi. Ia juga dirumuskan sebagai Hak Atas Kekayaan Intelektual. Kemampuan otak untuk menulis, berhitung, berbicara, mengingat fakta dan menghubungkan berbagai fakta menghasilkan ilmu pengetahuan dan teknologi, disebut juga sebagai fungsi preposisi verbal linguistis, logis dan analitis yang merupakan pekerjaan belahan otak kiri.

Dengan beberapa uraian diatas, semakin jelaslah kepada kita tentang pengertian asal usul kata "Intelectual Property Right "atau Hak Atas Kekayaan Intelektual. Tidak semua orang dapat dan mampu mempekerjakan otak (nalar, ratio, intelektual) secara maksimal. Oleh karena itu tidak semua orang dapat menghasilkan "intelectual property right", hanya orang yang mampu mempekerjakan otaknya sajalah yang dapat menghasilkan hak kebendaan yang disebut "intellectual property right". Itu pula lah sebabnya hasil kerja otak yang membuahkan hak atas kekayaan intelektual itu bersifat eksklusif dan hanya orang tertentu saja yang dapat melahirkan hak semacam itu. Berkembangnya peradaban manusia, dimulai dari kerja otak itu.

Saat ini pengaturan tentang masing masing bidang Hak Kekayaan Intelektual sudah terangkum didalam Undang Undang yang sudah ada di Indonesia seperti:

a. Hak Cipta diatur dalam UU Nomor 28 tahun 2014.

b. Paten diatur dalam UU nomor 14 Tahun 2001.

c. Merek diatur dalam UU Nomor 15 Tahun 2001.

d. Perlindungan Varietas`Baru Tanaman, diatur UU Nomor 29 Tahun 2000.

e. Rahasia Dagang diatur dalam UU Nomor 30 Tahun 2000.

f. Desain Industri diatur dalam UU Nomor 31 Tahun 2000.

g. Desain Tata Letak Sirkuit Terpadu diatur dalam UU Nomor 32 Tahun 2000.

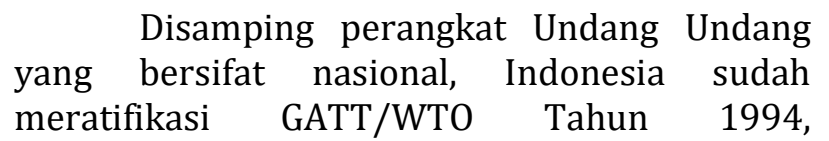

meratifikasi beberapa konvensi atau traktat internasional antara Konvensi Paris yang diratifikasi melalui Keppres`No. 15 Tahun 1997, Patent Cooperation Treaty yang diratifikasi melalui Keppres No. 16 Tahun 1997, Trade Mark Law Treaty diratifikasi melalui Keppres No. 17 tahun 1997, Konvensi Bern yang diratifikasi melalui Keppres No. 18 Tahun 1997, serta WIPO Copyright Treaty yang diratifikasi melalui Keppres No. 19 Tahun 1997.

Dengan demikian lengkaplah sudah Negara mempunyai perangkat hukum yang mampu melindungi Hak Kekayaan Intelektual bagi kreasi, cipta dan Kekayaan Intelektual bagi seluruh warga negara. Indonesia sudah melahirkan banyak UU yang terkait dengan Hak Kekayaan Intelektual dan sudah banyak meratifikasi UU yang berlaku di dunia Internasional.

Dunia Usaha Kecil Menengah (UKM), Penelitian dan Pengembangan (Litbang), Perguruan Tinggi, Pelaku Usaha, Konsultan HKI dan Pemangku Kepentingan tidak perlu ragu dan takut untuk memberantas pembajakan. Setiap pelaku pembajakan dan perampasan hak adalah tindakan kriminal dan berhak mendapatkan ganjaran yang setimpal dalam sistim hukum Nasional.

\section{Hak Cipta}

Unsur-unsur yang menjadi sistem perlindungan hak cipta berdasarkan UndangUndang Nomor 28 tahun 2014 tentang Hak Cipta adalah sebagai berikut :

a. Hak Cipta

b. Pencipta

c. Ciptaan

d. Pemegang Hak Cipta

e. Hak Terkait

f. Pelaku Pertumjukan

g. Produser Fonogram

h. Lembaga Penyiaran

i. Program Komputer

j. Potret

k. Pengumuman

l. Penggadaan

m. Fiksasi

n. Penyiaran

o. Pendistribusian

p. Kuasa 
q. Permohonan

r. Lisensi

s. Royalty

t. Lembaga Manajemen Kolektif

u. Pembajakan

v. Penggunaan Secara Komersial

\section{Paten}

Beberapa unsur yang terdapat pada paten berdasarkan UU Nomor 14 Tahun 2001 dijelaskan sebagai berikut

a. Paten

Paten adalah hak ekslusif yang diberikan oleh negara kepada inventor atas hasil invensinya di bidang teknologi, yang untuk selama waktu tertentu melaksanakan sendiri invensinnza tersebut atau memberikan persetujuannya kepada pihak lain untuk melaksanakannya.

b. Invensi

Invensi adalah ide inventor yang di tuangkan ke dalam suatu kegiatan pemecahan masalah yang spesifik di bidang teknologi dapat berupa produk atau proses, atau penyempurnaan dan pengembangan produk atau proses.

c. Inventor.

Inventor adalah seorang yang secara sendiri atau beberapa orang yang secara bersamasama melaksanakan ide yang dituangkan ke dalam kegiatan yang menghasilkan invensi

d. Pemohon.

Pemohon adalah pihak yang mengajukan permohonan paten ke Ditjen KI.

\section{$2.1 \quad$ Merek}

Beberapa unsur yang terdapat pada merek berdasarkan UU Nomor 15 Tahun 2001 bisa dijelaskan sebagai berikut:

a. Merek adalah tanda yang berupa gambar, nama, kata, huruf-huruf, angka-angka, susunan warna atau kombinasi dari unsurunsur tersebut yang memiliki daya pembeda dan digunakan dalam kegiatan perdaganagan barang atau jasa.

b. Merek dagang adalah merek yang digunakan pada barang yang di perdagangkan oleh seseorang atau beberapa orang secara bersama-sama atau badan hukum untuk membdakan dengan barang-barang sejenis lainnya.

c. Merek jasa adalah merek yang digunakan pada jasa yang di perdagangkan oleh seseorang atau beberapa orang secara bersama sama atau badan hukum untuk membedakan dengan jasa - jasa sejenis lainnya

d. Merek kolektif adalah merek yang digunakan pada barang dan atau jasa dengan karakteristik yang sama yang diperdagangkan oleh beberapa orang atau badan hukum secara berama-sama untuk membedakan dengan barang dan/atau jasa sejenis lainnya.

\section{Desain Indsutri.}

Beberapa unsur yang terdapat pada Desain Indsutri berdasarkan UU Nomor 31 Tahun 2000 bisa dijelaskan sebagai berikut :

a. Desian industry adalah suatu kreasi tentang bentuk, konfigurasi, atau komposisi atau warna atau gabungan daripadannya yang berbentuk tiga dimensi atau dua dimensi yang memberikan kesan estitis dan dapat di wujudkan dalam pola tiga dimensi atau dua dimensi serta dapat di pakai untuk menghasilkan suatu produk, barang, komoditas industry, kerajinan tangan.

b. Pendesain adalah seorang atau beberapa orang yang menghasilkan desain industry.

c. Permohonan adalah permintaan pendaftaran desain industry yang diajukan kepada Direktorat Jenderal Kekayaan Intelektual Kementerian Hukum dan Hak Asasi Manusia.

d. Pemohon adalah pihak yang mengajukan permohonan yang mengajukan ke Ditjen KI.

e. Hak desain industry adalah hak ekslusif yang diberikan oleh negara Republik Indonesia kepada pendesain atas hasil kreasinnya untuk selama waktu tertentu melaksanakan sendiri, atau memberikan persetujuannya kepada pihak lain untuk melaksanakan hak tersebut. 


\section{Rahasia Dagang}

Beberapa unsur yang terdapat pada Rahasia Dagang berdasarkan UU Nomor 30 Tahun 2000 bisa dijelaskan sebagai berikut:

a. Rahasia dagang adalah informasi yang tidak diketahui oleh umum di bidang teknologi dan/atau bisnis, mempunyai nilai ekonomi karena berguna dalam kegiatan usaha dan dijaga kaerahasiaannya oleh pemilik rahasia dagang

b. Hak rahasia dagang adalah ha katas rahasia dagang yang timbul berdasarkan UndangUndang ini.

c. Lisensi adalah ijin yang diberikan oleh pemegang Hak Rahasia Dagang melalui suatu perjanjian berdasarkan 2.1p魚a pemberian hak (bukan pengalihan hak) untuk menikmati manfaat ekonom dari suatu rahasia dagang dalam jangka waktu tertentu dan syarat tertentu.

Perlindungan Varitas Tanaman Baru dan Desain Tata Letak Sirkuit Terpadu.

Untuk sementara dua jenis item terkait dengan tata letak sirkuit terpadu dan perlindungan varitas tanaman masih dibawa karena bersifat ekslusif masih dibawah pengelolaan Direktorat Hak Cipta dan tidak dibahas dalam tesis ini.

2.1.9

Jasa

\section{Penerimaan Administrasi Hukum Umum/} Hukum.

Direktorat Jenderal Administrasi Hukum Umum Kementerian Hukum dan Hak Asasi Manusia yang selanjutnya disebut Direktorat Jenderal Administrasi Hukum Umum adalah unit kerja kementerian yang mengelola Pelayanan Jasa Hukum. Pelayanan Jasa Hukum adalah pelayanan jasa hukum di bidang notariat, fidusia, dan kewarganegaraan. Direktur Jenderal Administrasi Hukum Umum melakukan pemantauan dan pembinaan teknis dalam hal pengelolaan, pelaporan PNBP dan penggunaan PNBP atas Pelayanan Jasa Hukum.

Dilihat dari bidang tugas dan fungsinya, peranan Direktorat Jenderal Administrasi Hukum Umum sangat strategis dalam melaksanakan kebijakan serta merumuskan standar, norma, pedoman, kriteria dan prosedur dibidang pelayanan hukum sesuai dengan ketentuan peraturan perundang-undangan yang berlaku. Direktorat Jenderal Administrasi Hukum Umum menyelenggarakan pelayanan publik yang berdasarkan prinsip kesederhanaan, kejelasan, kepastian waktu, akurasi, keamanan, tanggungjawab, kelengkapan sarana, dan prasarana, kemudahan akses, kedisiplinan, kesopanan, keramahan dan kenyamanan. Hal inilah yang menjadi landasan pelayanan Direktorat Jenderal Administrasi Hukum Umum dalam melaksanakan pelayanan kepada masyarakat. DIPA pada Direktorat Jenderal Administrasi Hukum Umum bersumber dari Rupiah Murni (RM) dan bersumber dari Penerimaan Negara Bukan Pajak (PNBP).

\section{Penerimaan Keimigrasian.}

Keimigrasian sebagaimana yang ditentukan di dalam Bab 1 Pasal 1 (1) UndangUndang Nomor 9 Tahun 1992 Lembaran Negara Tahun 1992, Nomor 33 Tentang Keimigrasian adalah hal ihwal lalu lintas orang yang masuk atau keluar wilayah Negara Republik Indonesia dan pengawasan orang asing di Indonesia. Hukum Keimigrasian merupakan bagian dari sistem hukum yang berlaku di Indonesia, bahkan merupakan subsistem dari Hukum Administrasi Negara.

Fungsi keimigrasian merupakan fungsi penyelenggaraan administrasi negara atau penyelenggaraan administrasi pemerintahan, oleh karena itu sebagai bagian dari penyelenggaraan kekuasaan eksekutif, yaitu fungsi administrasi negara dan pemerintahan, maka hukum keimigrasian dapat dikatakan bagian dari bidang hukum administrasi negara.

Kegiatan pokok dilakukan meliputi pelayanan dokumen perjalanan, visa dan fasilitas keimigrasian, perumusan kebijakan teknis dokumen perjalanan, visa, ijin masuk, izin bertolak, dan fasilitas keimigrasian, persetujuan izin tinggal dan status keimigrasian, perumusan kebijakan teknis izin tinggal, alih status keimigrasian, status keimigrasian dan surat keterangan keimigrasian serta izin tinggal khusus/darurat, pendeteksian pelanggaran atau kejahatan keimigrasian, perumusan rancangan kebijakan teknis intelejen keimigrasian, penyidikan dan penindakan pelaku tindak 
pidana keimigrasian, penyajian data cegah tangkal, perumusan kebijakan teknis penyidikan dan penindakan keimigrasian, kerjasama luar negeri keimigrasian, perumusan kebijakan teknis lintas batas dan kerjasama keimigrasian antar negara dan organisasi internasional, aplikasi on line 24 jam, perumusan kebijakan teknis sistim informnasi keimigrasian, perencanaan, pelaksanaan, pengendalian dan pelaporan.

\section{PNBP Keimigrasian}

Berdasarkan Peraturan Pemerintah Nomor 45 Tahun 2014 tentang Jenis dan Tarif Penerimaan Negara Bukan Pajak yang berlaku pada Kementerian Hukum dan Hak Asasi Manusia, PNBP keimigrasian terdiri dari berbagai macam penerimaan yang meliputi 72 jenis dan tarif PNBP Keimigrasian yang secara garis besarnya terdiri dari:

1. Surat Perjalanan Republik Indonesia

2. Visa

3. Izin Keimigrasian

4. Izin Masuk Kembali (Re-entry Permit)

5. Biaya Beban

6. Smart Card

7. Kartu Perjalanan Pebisnis Asia Pacific Economic Cooperation (KPP APEC) / APEC Business Travel Card (ABTC).

8. KPP APEC Pengganti yang Hilang/Rusak yang Masih Berlaku Disebabkan Karena Kelalaian

9. Fasilitas Keimigrasian (Affidavit) Bagi Anak Berkewarganegaraan Ganda Elektronik .

10. Fasilitas Keimigrasian (Affidavit) Bagi Anak Berkewarganegaraan

Ganda Elektronik .

11. Surat Keterangan Keimigrasian

12. Jasa Penggunaan Teknologi Sistem Informasi Manajemen Keimigrasian

2.1.

Ijin Penggunaan PNBP Keimigrasian.

\begin{tabular}{lllr}
\multicolumn{2}{c}{ Penggunaan } & perolehan & PNBP \\
Keimigrasian & tersebut & didasarkan & kepada \\
Keputusan & Menteri & Keuangan & Nomor
\end{tabular}
407/KMK.02/2010 tanggal 4 Oktober 2010 tentang Persetujuan Penggunaan Sebagian Dana PNBP pada Direktorat Jenderal Imigrasi
Kementerian Hukum dan HAM, yang menyetujui penggunaan sebagian dana PNBP pada Direktorat Jenderal Imigrasi paling tinggi sebesar 70,94\% (tujuh puluh koma sembilan puluh empat persen) dan telah dirubah dengan Keputusan Menteri Keuangan tersebut di atas Nomor 43/KMK.02/2013 tentang Perubahan Atas Keputusan Menteri Keuangan Nomor 407/KMK.02/2010 tentang Persetujuan Penggunaan Sebagian dana PNBP pada Direktorat Jenderal Imigrasi Kementerian Hukum dan HAM. Penggunaan sebagian dana tersebut dapat digunakan untuk membiayai kegiatan yang meliputi:

1. Penelitian dan pengembangan perangkat teknologi di bidang keimigrasian;

2. Pembinaan dan pengelolaan PNBP bidang keimigrasian;

3. Penegakan hukum bidang keimigrasian;

4. Pendidikan dan pelatihan bidang keimigrasian;

5. Peningkatan kualitas sumber daya manusia bidang keimigrasian;

6. Pembangunan, pengadaan, dan pemeliharaan sarana dan prasarana keimigrasian;

7. Pelaksanaan kegiatan operasional keimigrasian di Tempat Pemeriksaan Imigrasi dan Pos Lintas Batas.

\section{Pokok - Pokok Kebijakan PNBP Sektor Keimigrasian.}

Dengan semakin besarnya peran PNBP untuk mendanai pembangunan, Direktorat Jenderal Imigrasi terus melakukan gebrakangebrakan dengan program-program dan kebijakan yang diarahkan untuk terus meningkatkan jumlah penerimaan PNBP dengan cara meningkatkan kualitas pelayanan, optimalisasi berbagai sumber daya yang ada dan menerapkan kebijakan-kebijakan yang tepat yang lebih berorientasi terhadap peningkatan kualitas pelayanan. Pokok-pokok kebijakan tersebut diantaranya:

\section{Pembentukan Unit Layanan Paspor (ULP)}

Unit Layanan Paspor (ULP) merupakan bentuk pelayanan yang dilakukan oleh Kantor Imigrasi (Kanim) tertentu dimana terdapat 
pelayanan yang sangat banyak sehingga diperlukan penambahan fungsi pelayanan kepada masyarakat berupa Unit Layanan Paspor yang tujuannya antara lain untuk memecah konsentrasi pelayanan yang dilakukan Kanim agar tidak terlalu menumpuk pada Kanim, juga untuk lebih mendekatkan pelayanan yang dilakukan Kanim agar lebih dekat kepada masyarakat. Cara pelayanan yang dilakukan seperti ini selain dapat meningkatkan fungsi pelayanan, juga dapat menarik masyarakat untuk membuat paspor maupun memanfaatkan layanan keimigrasian lainnya karena kemudahan layanan yang diberikan.

Selama periode tahun 2013, telah dibentuk dua ULP pada Kanim Kelas I Khusus Jakarta Selatan berdasarkan Keputusan Menteri Hukum dan HAM Nomor M.HH-02.0T.01.01 Tahun 2013 tentang Pembentukan Unit Layanan Paspor Kantor Imigrasi Kelas I Khusus Jakarta Selatan, masing-masing satu ULP pada Kanim Kelas I Khusus Jakarta Barat dan Kanim Kelas I Khusus Surabaya berdasarkan Keputusan Menteri Hukum dan HAM Nomor M.HH04.0T.01.01 Tahun 2013 tentang Pembentukan Unit Layanan Paspor Kantor Imigrasi Kelas I Khusus Jakarta Barat dan Unit Layanan Paspor Kantor Imigrasi Kelas I Khusus Surabaya.

Pada tahun 2014 telah dibentuk ULP pada Kantor Imigrasi Kelas I Bandung berdasarkan Keputusan Menteri Hukum dan HAM Nomor M.HH-02.0T.01.01 Tahun 2014 tentang Pembentukan Unit Layanan Paspor Kantor Imigrasi Kelas I Bandung. Sedangkan pada tahun 2015, akan dibentuk ULP pada Kanim Kelas I Khusus Medan, Kanim Kelas I Tangerang, Kanim Kelas I Semarang, Kanim Kelas I Banjarmasin dan Kanim Kelas I Makassar berdasarkan Keputusan Menteri Hukum dan HAM Nomor M.HH-01.0T.01.01 Tahun 2015 tentang Pembentukan Unit Layanan Paspor Kantor Imigrasi Kelas I Khusus Medan, Kantor Imigrasi Kelas I Tangerang, Kantor Imigrasi Kelas I Semarang, Kantor Imigrasi Kelas I Banjarmasin dan Kantor Imigrasi Kelas I Makassar serta Instruksi Presiden Nomor 7 Tahun 2015 tentang Aksi Pencegahan dan Pemberantasan Korupsi Tahun 2015.
Dalam Rencana Strategis (Renstra)

Ditjen Imigrasi, pembentukan ULP menjadi program Quick Win tahun 2015 sampai dengan 2019 sebanyak 25 ULP.

\section{Penambahan Penerapan Autogate pada Tempat Pemeriksaan Imigrasi}

Sistem autogate merupakan sistem yang digunakan dalam sarana perlintasan keimigrasian melalui pintu perlintasan otomatis bagi setiap orang yang akan masuk dan keluar wilayah Indonesia dimana untuk membuka pintu tersebut terlebih dahulu diperlukan prosedur pemindaian paspor dan sidik jari yang tersedia pada peralatan autogate. Salah satu tujuan penerapan sistem autogate yaitu untuk memudahkan, mempercepat maupun menyederhanakan proses pemeriksaan keimigrasian bagi masyarakat pemegang paspor elektronik maupun paspor biasa yang akan masuk maupun keluar wilayah Indonesia.

\section{Pengembangan Sistem Layanan Visa Online}

Penerapan sistem layanan visa secara online merupakan bentuk peningkatan pelayanan keimigrasian dimana pengajuan aplikasi permohonan visa dilakukan melalui internet. Layanan Visa Online diberikan untuk memudahkan orang yang akan berkunjung ke Indonesia tanpa harus mendatangi Kantor Perwakilan Indonesia di Luar Negeri sehingga pengajuan layanan visa dapat dilakukan dimana saja. Dengan diluncurkannya layanan visa secara online, diharapkan semakin banyak orang asing yang akan datang ke Indonesia baik dengan tujuan berlibur maupun berbisnis sehingga secara tidak langsung akan mendatangkan devisi dan pendapatan bagi masyarakat.

\section{Pengembangan Sistem Penerbitan Paspor Berbasis One Stop Service}

Sebagai pengembangan dari kebijakan penerbitan Paspor Biasa yang berlaku saat ini, pada tahun 2014 Direktorat Jenderal Imigrasi telah mengembangkan Sistem Penerbitan Paspor Berbasis One Stop Service sebagai upaya meningkatkan pelayanan prima, memberikan perlindungan bagi masyarakat dan petugas Imigrasi serta meningkatkan kepuasan 
masyarakat yang ditandai dengan berkurangnya keluhan-keluhan masyarakat. Upaya peningkatan pelayanan publik ini, telah diimplementasikan tahun 2014. Kebijakan peningkatan pelayanan keimigrasian ini dimaksudkan untuk mengatasi praktek percaloan dan pungutan liar melalui penguatan kesisteman yang pada akhirnya akan memberikan perlindungan bagi kedua belah pihak baik bagi pemohon maupun pegawai. Kalaupun permohonan menggunakan jasa pihak ketiga tidak akan mengakibatkan perubahan bisnis proses.

\section{Pengembangan Bussiness Process Pelayanan Izin Tinggal}

Selain pengembangan penerbitan paspor berbasis one stop service, Direktorat Jenderal Imigrasi juga sedang mengembangkan Business Process Pelayanan Izin Tinggal terhadap Orang Asing, hal ini dilakukan sebagai upaya meningkatkan pelayanan prima kepada masyarakat. Melalui pengembangan Business Process pelayanan izin tinggal, prosedur pelayanan pemberian izin tinggal bagi orang asing akan menjadi lebih sederhana. Selain itu dengan pengembangan Business Process Pelayanan Izin Tinggal ini akan lebih meningkatkan transparansi dan akuntabilitas dalam pemungutan PNBP Keimigrasian.

\section{Penerapan e-passport di wilayah Jabodetabeka \\ Untuk merespon tuntutan dunia} internasional dalam penggunaan paspor elektronik (e-passport), Direktorat Jenderal Imigrasi akan meningkatkan penerbitan $e$ passport dengan menambah Kantor Imigrasi yang dapat menerbitkan e-passport. Sampai saat ini Kantor Imigrasi yang menerbitkan e-passport jumlahnya masih terbatas pada Kantor Imigrasi di wilayah Jakarta dan beberapa kota besar di luar wilayah Jakarta dengan jumlah 9 Kantor Imigrasi. Pada tahun 2015 disamping berencana akan menerapkan design paspor baru juga akan menambah Kantor Imigrasi yang menerbitkan $e$ passport bahkan penerapan e-passport secara menyeluruh akan dilaksanakan paling lambat akhir tahun 2015. Kebijakan ini sudah barang tentu akan berdampak pada penganggaran yang lebih besar karena untuk mencetak blanko $e$ passport lebih tinggi dari pada mencetak blanko paspor non elektronik. Namun demikian, dengan penerapan e-passport akan mendongkrak perolehan PNBP Keimigrasian karena tarif $e$ passport lebih tinggi dari paspor non elektronik.

\section{Penambahan UPT yang menerbitkan e-Kitas dan e-Kitap.}

Dalam rangka meningkatkan kualitas keamanan dokumen Kitas dan Kitap, Direktorat Jenderal Imigrasi akan menambah Kantor Imigrasi yang menerbitkan e-Kitas dan e-Kitap. Saat ini sudah terdapat 25 Kantor Imigrasi yang menerbitkan e-Kitas dan e-Kitap. Dalam tahun 2015 akan ditambah 25 Kantor Imigrasi yang menerbitkan e-Kitas dan e-Kitap dan diharapkan tahun 2015 seluruh Kantor Imigrasi sudah dapat menerbitkan e-Kitas dan e-Kitap. Bertambahnya Kantor Imigrasi yang dapat memberikan pelayanan e-Kitas dan e-Kitap disamping akan meningkatkan pelayanan dan meningkatkan kualitas pengamanan dokumen keimigrasian, juga akan meningkatkan perolehan PNBP Keimigrasian.

\section{METODE PENELITIAN}

Metode yang di pakai untuk menguji hipotesis ini adalah memakai uji regresi berganda (multiple regression). Uji regresi berganda digunakan untuk melihat pengaruh tiga variable bebas atau lebih terhadap satu variabel terikat. Input untuk penelitian ini diperoleh dari laporan keuangan selama periode 2009 sd 2014. Sedangkan untuk data-data kepustakaan, di ambil dari jurnal ilmiah, buku teks penunjang, media cetak dan internet. Data tersebut nantinya akan di olah melalui aplikasi program SPSS version 19.0 dengan menggunakan menu REGRESSION. Kemudian hasil dari data tersebut akan diinterpretasikan untuk dapat mencapai tujuan dari penelitian ini.

\section{HASIL PENELITIAN DAN PEMBAHASAN}

Berdasarkan data yang diinput dari Laporan Keuangan Tahunan Kementerian Hukum dan HAM RI dari tahun 2009 sampai 
dengan 2014 maka didapat total penerimaan kekayaan intelektual, total penerimaan administrasi hukum umum, total penerimaan keimigrasian, dan total pendapatan negara bukan pajak.

Tabel 4

Penerimaan Negara Bukan Pajak Kementerian Hukum dan HAM RI

\begin{tabular}{|c|c|c|c|c|}
\hline Tahun & $\begin{array}{c}\text { Penerimaan } \\
\text { Kekayaan } \\
\text { Intelektual }\end{array}$ & $\begin{array}{c}\text { Penerimaan } \\
\text { Administrasi } \\
\text { Hukum } \\
\text { Umum }\end{array}$ & $\begin{array}{c}\text { Penerimaan } \\
\text { Keimigrasian }\end{array}$ & $\begin{array}{c}\text { Penerimaan } \\
\text { Negara } \\
\text { Bukan Pajak }\end{array}$ \\
\hline 2009 & 170,664 & 90,936 & 537,565 & $1,500,296$ \\
\hline 2010 & 214,240 & 122,232 & 779,532 & $1,980,596$ \\
\hline 2011 & 224,778 & 143,495 & 848,247 & $2,127,423$ \\
\hline 2012 & 249,348 & 198,442 & 945,976 & $2,369,042$ \\
\hline 2013 & 268,470 & 454,676 & $1,180,392$ & $2,969,070$ \\
\hline 2014 & 289,487 & 632,782 & $2,984,172$ & $4,020,829$ \\
\hline
\end{tabular}

Sumber : Diolah dari Laporan Keuangan hasil Audit BPK

Untuk melihat Fluktuatif data Penerimaan Negara Bukan Pajak Kementerian Hukum dan HAM RI selama 6 tahun dapat dlihat dari grafik berikut ini.

Grafik 1. Fluktuatif Penerimaan Negara Bukan Pajak Kementerian Hukum dan HAM RI

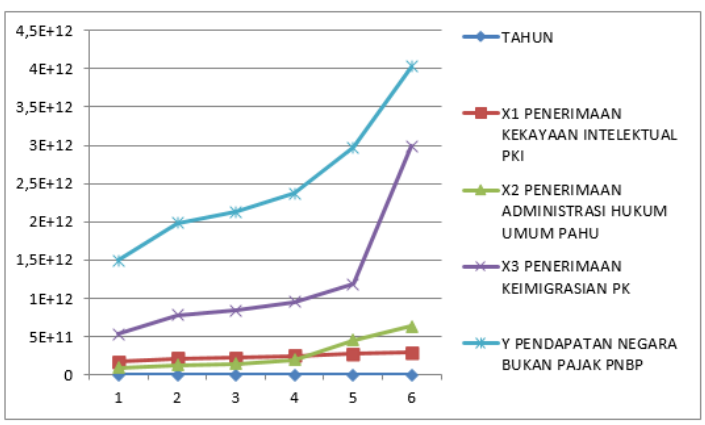

Sumber : Diolah dari Laporan Keuangan

Dari grafik 1 diatas dapat dianalisis yaitu fluktuatif selama 6 tahun (2009 - 2014) pada Penerimaan Negara Bukan Pajak Kementerian Hukum dan HAM RI, bahwa Penerimaan Keimigrasian mempunyai nilai yang paling baik diantara penerimaan administrasi hukum umum dan penerimaan kekayaan intelektual. Penerimaan keimigrasian dari tahun ke tahun memiliki peningkatan yang semakin meningkat, terutama pada tahun 2014.

Tabel 6

Rasio Penerimaan Negara (X1, X2, X3) terhadap Penerimaan Negara Bukan Pajak Kementerian Hukum dan HAM RI

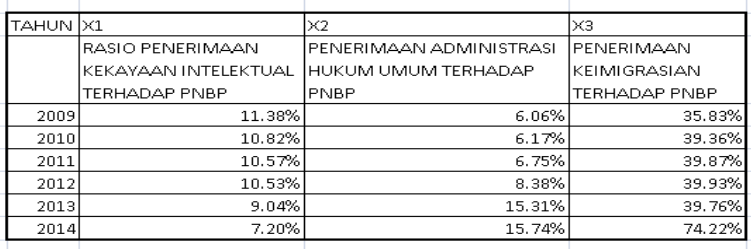

Sumber : Diolah dari Laporan Keuangan

Grafik 2. Rasio Penerimaan Negara (X1, X2, X3) terhadap Penerimaan Negara Bukan Pajak Kementerian Hukum dan HAM RI

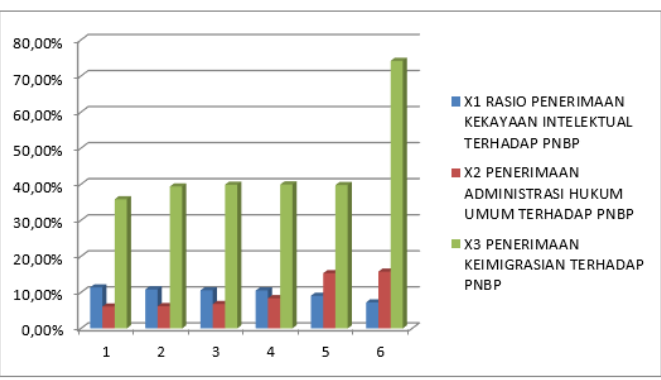

Sumber : Diolah dari Laporan Keuangan

Berdasarkan tabel 5 dan grafik 2 bahwa penerimaan kekayaan intelektual memiliki sumbangsih terhadap PNBP pada tahun 2009 sebesar 11,38\%; tahun 2010 sebesar 10,82\%; tahun 2011 sebesar 10,57\%; tahun 2012 sebesar 10,53\%; tahun 2013 sebesar 9,04\%; dan tahun 2014 sebesar 7,20\%. Untuk penerimaan administrasi hukum umum memiliki sumbangsih terhadap PNBP pada tahun 2009 sebesar 6,06\%; tahun 2010 sebesar 6,17\%; tahun 2011 sebesar 6,75\%; tahun 2012 sebesar 8,38\%; tahun 2013 sebesar 15,35\%; dan tahun 2014 sebesar 15,74\%. Sedangkan untuk penerimaan keimigrasian memiliki sumbangsih terhadap PNBP pada tahun 2009 sebesar 35,83\%; tahun 2010 sebesar 39,36\%; tahun 2011 sebesar 39,87\%; tahun 2012 sebesar 39,93\%; tahun 2013 sebesar 39,76\%; dan tahun 2014 sebesar $74,22 \%$. 


\section{Analisis Deskriptif Secara Statistik}

Berdasarkan data yang diinput dari Laporan Keuangan Tahunan dari tahun 2009 sampai dengan 2014 ke dalam program statistik SPSS maka dapat dilihat nilai maksimum, minimum, mean dan standar deviation dari masing-masing variabel penelitian dapat dilihat pada table 6 sebagai berikut :

Tabel 6

Perhitungan Nilai Maksimum, inimum, Mean, dan Standar Deviation

\section{Descriptive Statistics}

\begin{tabular}{|l|c|r|r|r|c|}
\hline & $\mathrm{N}$ & \multicolumn{1}{|c|}{ Min } & \multicolumn{1}{c|}{ Max } & Mean & $\begin{array}{c}\text { Std. } \\
\text { Deviation }\end{array}$ \\
\hline PKI & 6 & 170664 & 289487 & 236164,50 & 42335,306 \\
\hline PAHU & 6 & 90936 & 632782 & 273760,50 & 219387,564 \\
\hline PK & 6 & 537565 & 2984172 & 212647,33 & 892923,995 \\
\hline PNBP & 6 & 1500296 & 4020829 & 494542,67 & 889710,182 \\
\hline $\begin{array}{l}\text { Valid N } \\
\text { (listwise) }\end{array}$ & 6 & & & & \\
\hline
\end{tabular}

Sumber : Output SPSS Versi 19.

Berdasarkan hasil perhitungan pada table 6 pada 6 sampel, menunjukkan tidak terdapat penyimpangan pada setiap variabel.

Hasil pada PNBP, yang menunjukkan bahwa data variabel PNBP mengindikasikan hasil yang baik, hal tersebut dikarenakan standart deviation yang mencerminkan lebih kecil daripada nilai rata-ratanya. Hal yang sama juga terjadi pada 3 variabel independen yaitu PKI, PAHU dan PK. Dimana rata-rata PKI selama periode pengamatan (2009 - 2014) sebesar 236164,50 dengan standart deviation (SD) sebesar 42335,306. Sedangkan rata-rata PAHU selama periode pengamatan (2009 - 2014), rataratanya (mean) sebesar 273760,50 dengan standart deviation (SD) sebesar 219387,564, Dan rata-rata PK selama periode pengamatan (2009 - 2014), rata-rata (mean) sebesar 1212647,33 dengan standart deviation (SD) sebesar 892923,995.

\section{Uji asumsi klasik}

Uji asumsi klasik merupakan prasyarat analisis regresi linear berganda. Dari hasil perhitungan sampel selama 6 tahun, maka dalam penelitian ini perlu dilakukan pengujian asumsi klasik terlebih dahulu yang meliputi: uji normalitas, uji multikolinieritas, uji autokorelasi, dan uji heteroskedastisitas yang dilakukan sebagai berikut:

\section{Uji Normalitas}

Uji normalitas bertujuan untuk menguji apakah dalam model regresi, variabel pengganggu atau residual memiliki distribusi normal atau tidak, salah satu cara termudah untuk melihat normalitas adalah dengan melihat histrogram yang membandingkan antara data observasi dengan distribusi yang mendekati distribusi normal. Berdasarkan Gambar $3 \mathrm{Uji}$ Normalitas yang terbentuk sebagai berikut:

\section{Gambar 3 \\ Uji Normalitas}

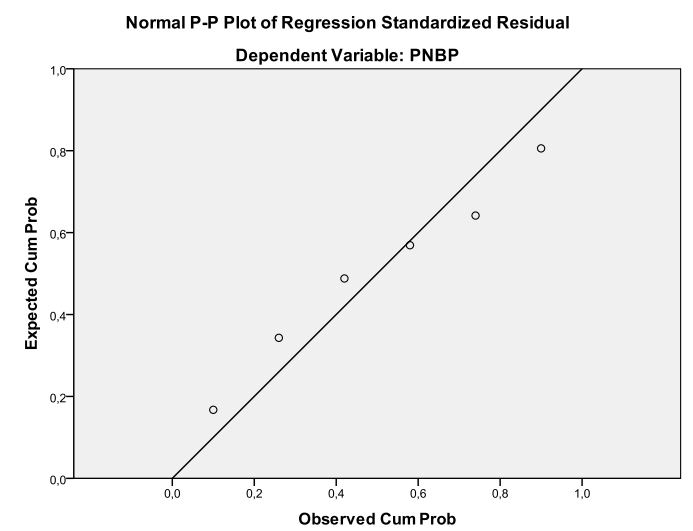

Sumber : Output SPSS Versi 19

Jika dilihat berdasarkan grafik normal plot terlihat titik-titik menyebar disekitar garis diagonal, serta penyebaran mendekati dari garis diagonal. Hal ini menunjukkan bahwa grafik menunjukkan pola distribusi normal, maka model regresi memenuhi asumsi normalitas.

Untuk melengkapi uji grafik dilakukan juga uji statistik lain yang dapat digunakan untuk menguji normalitas residual adalah uji statistic non parametik Kolmogrov-Smirnov (KS) dapat dilihat pada table 7 , sebagai berikut: 
Tabel 7

Uji Statistik Non Paramaterik

One-Sample Kolmogorov-Smirnov Test

\begin{tabular}{|c|c|c|}
\hline & & $\begin{array}{c}\text { Unstandardized } \\
\text { Residual }\end{array}$ \\
\hline $\mathrm{N}$ & & 6 \\
\hline \multirow[t]{2}{*}{ Normal Parameters ${ }^{a, b}$} & Mean &, 0000000 \\
\hline & Std. Deviation & 17927,3003207 \\
\hline \multirow[t]{3}{*}{ Most Extreme Differences } & Absolute & , 148 \\
\hline & Positive & ,116 \\
\hline & Negative &,- 148 \\
\hline Kolmogorov-Smirnov Z & &, 362 \\
\hline Asymp. Sig. (2-tailed) & & 999 \\
\hline
\end{tabular}

Untuk menentukan data dengan uji Kolmogorov-Smirnov, nilai signifikansi harus di atas 0,05 atau 5\% (Imam Ghozali, 2006). Pengujian terhadap normalitas data dengan menggunakan uji Kolmogorov-Smirnov menunjukkan bahwa nilai KolmogorovSmirnovZ sebesar 0,362 dan nilai Asymp.Sig.(2tailed) sebesar 0,999 mempunyai nilai signifikansi di atas 0,05, sehingga data yang ada terdistribusi normal. Hal tersebut mengindikasikan bahwa variabel independen yang digunakan dalam penelitian ini tidak terdapat data yang ekstrim yang dapat mengakibatkan hasil penelitian menjadi bias sehingga dapat digunakan untuk memprediksi PNBP Kementerian Hukum dan HAM RI periode 2009 - 2014.

\section{Uji Multikolinearitas}

Untuk mendeteksi ada tidaknya gejala multikolinearitas antar variabel independen digunakan variance inflation factor (VIF). Sampel hasil yang ditunjukkan dalam output SPSS maka besarnya VIF dari masing-masing variabel independen dapat dilihat pada tabel 8 sebagai berikut :

Tabel 8

Hasil Perhitungan VIF

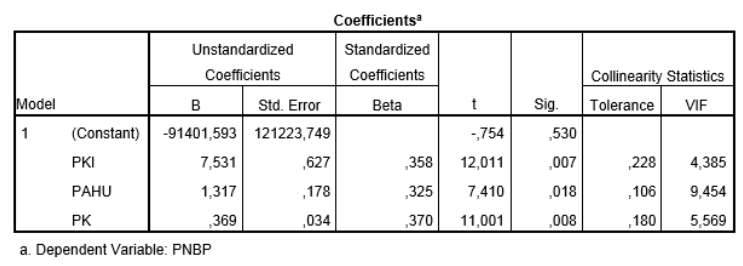

Tabel 8 menunjukkan bahwa ketiga variabel independen tidak terjadi multikolinearitas karena nilai Variance Inflation Factor VIF $<10$. Dengan demikian 3 variabel independen (PKI, PAHU, $P K$ ) dapat digunakan untuk memprediksi PNBP selama periode pengamatan 2009 - 2014.

\section{Uji Autokorelasi}

Penyimpangan autokorelasi dalam penelitian diuji dengan uji Durbin-Watson (DWtest). Hal tersebut untuk menguji apakah model linier mempunyai korelasi antara disturbence error pada periode $t$ dengan kesalahan pada periode t-1 (sebelumnya). Hasil regresi dengan level of significance 0,05 $(\mathrm{a}=0,05)$ dengan sejumlah variabel independen $(\mathrm{k}=3)$ dan banyaknya data $(n=6)$. Adapun hasil dari uji autokorelasi dapat dilihat pada Tabel 4.5 sebagai berikut :

Tabel 9

Hasil Uji Autokorelasi

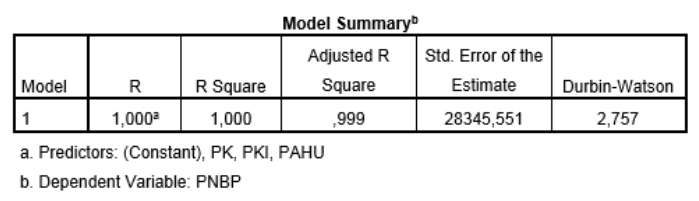

Berdasarkan hasil hitung Durbin Watson, penyimpangan autokorelasi sebesar 2,757. sedangkan dalam tabel DW untuk " $k$ " $=3$ dan $N=6$ besarnya DW-tabel : dl (batas luar) $=1,1010$, du (batas dalam) $=1,6565,4-\mathrm{du}=2,3435$ dan $4-$ $\mathrm{dl}=2,899$. Oleh karena nilai DW 2,757 lebih besar dari batas dalam (du) 1,6565 dan DW kurang dari 4 -1,1010, maka dapat disimpulkan bahwa DW-test tidak ada autokorelasi positif atau negatif atau dapat disimpulkan tidak terdapat autokorelasi.

\subsubsection{Uji Heterokedastisitas}

Untuk menentukan heteroskedastisitas juga dapat menggunakan grafik scatterplot, titiktitik yang terbentuk harus menyebar secara acak , tersebar baik diatas maupun dibawah angka 0 pada sumbu Y. Hasil uji heteroskedastisitas dapat dilihat melalui grafik Scatterplot, yang ditunjukkan pada gambar 4.2 dibawah ini 


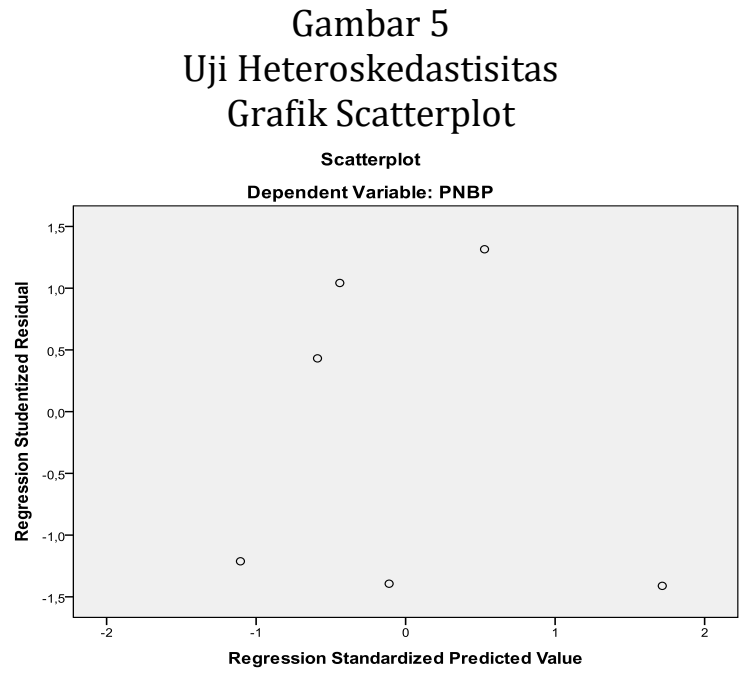

Dari grafik scatterplot terlihat bahwa titiktitik menyebar secara acak serta tersebar baik diatas maupun dibawah angka nol (0) pada sumbu Y, tidak berkumpul disatu tempat, serta tidak membentuk pola tertentu sehingga dapat disimpulkan bahwa tidak terjadi heteroskedastisitas pada model regresi dalam artian bahwa varian semua variabel ini menunjukkan variabel independen (PK, PKI dan PAHU) dapat digunakan untuk memprediksi PNBP pada Kementerian Hukum dan HAM RI selama periode 2009 - 2014.

\section{Analisis Regresi Linear Berganda}

Analisis pengaruh rasio keuangan (PK, PKI, PAHU) terhadap PNBP Kementerian Hukum dan HAM RI dapat dilihat dari hasil analisis regresi linear berganda. Pengujian koefisien regresi bertujuan untuk menguji signifikansi hubungan antara variabel independen (X) dengan variabel dependen (Y) baik secara bersama-sama (dengan uji F) maupun secara individual (dengan uji t) serta dengan uji koefisien determinasi. Dalam penelitian ini uji hipotesis yang digunakan meliputi; uji parsial (ttest), uji pengaruh simultan (F-test), uji koefisien determinasi $\left(\mathrm{R}^{2}\right)$.

\section{Uji Koefisien Determinasi $\left(\mathbf{R}^{2}\right)$}

Uji koefisien determinasi digunakan untuk mengetahui persentase pengaruh variabel independen terhadap variabel dependen. Dari sini akan diketahui seberapa besar variabel independen akan mampu menjelaskan variabel dependennya, sedangkan sisanya dijelaskan oleh sebab-sebab lain di luar model. Berdasarkan hasil output SPSS besarnya nilai adjusted $\mathrm{R}^{2}$ dapat dilihat pada table 4.6 sebagai berikut:

Table 10

Uji Koefisien Determinasi $\left(\mathrm{R}^{2}\right)$

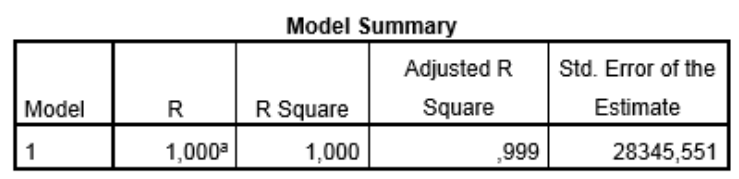

a. Predictors: (Constant), PK, PKI, PAHU

Dilihat dari table diatas, nilai koefisien Determinasi (adjusted $\mathrm{R}^{2}$ ) sebesar 0,999 atau 99,9\% hal ini berarti 99,9\% variasi PNBP yang bisa dijelaskan oleh variasi dari ketiga variabel independen yaitu PKI, PAHU dan PK. Sedangkan sisanya sebesar 0,01\% dijelaskan oleh faktor lain yaitu penerimaan lainnya di Kementerian Hukum dan HAM RI. Standar Error of estimate (SEE) sebesar 028345,551. Makin kecil nilai SEE akan membuat model regresi semakin tepat dalam memprediksi variabel dependen.

\section{Uji F (uji pengaruh secara simultan)}

Berdasarkan hasil output SPSS nampak bahwa pengaruh secara bersama-sama 3 variabel independen tersebut (PKI, PAHU, PK) terhadap PNBP seperti ditunjukkan pada table 4.7 sebagai berikut :

Table 11

Uji pengaruh secara simultan (F)

\begin{tabular}{|c|c|c|c|c|c|c|}
\hline \multicolumn{7}{|c|}{ ANOVAD $^{\circ}$} \\
\hline Model & & Sum of Squares & df & Mean Square & $\mathrm{F}$ & Sig. \\
\hline \multirow[t]{3}{*}{1} & Regression & 3,956E12 & 3 & 1,319E12 & 1641,344 &, $001^{\mathrm{a}}$ \\
\hline & Residual & $1,607 \mathrm{E} 9$ & 2 & $8,035 \mathrm{E} 8$ & & \\
\hline & Total & 3,958E12 & 5 & & & \\
\hline
\end{tabular}

b. Dependent Variable: PNBP

Dari hasil perhitungan yang diperoleh nilai F sebesar 1641,344 dan nilai signifikan sebesar 0,001. Karena nilai signifikansi lebih kecil dari 5\% atau 0,05 maka hipotesis 4 diterima. Ini berarti bahwa variabel Penerimaan Kekayaan Intelektual, Penerimaan Administrasi 
Hukum Umum dan Penerimaan Keimigrasian secara bersama-sama berpengaruh signifikan terhadap Penerimaan Negara Bukan Pajak pada Kementerian Hukum dan HAM RI.

\section{Uji t (Uji pengaruh secara parsial)}

Berdasarkan hasil output SPSS nampak bahwa pengaruh secara parsial 3 variabel independen tersebut (PKI, PAHU, PK) terhadap PNBP seperti ditunjukkan pada table 4.7 sebagai berikut:

Table 12

Uji t (Uji Pengaruh Secara Parsial)

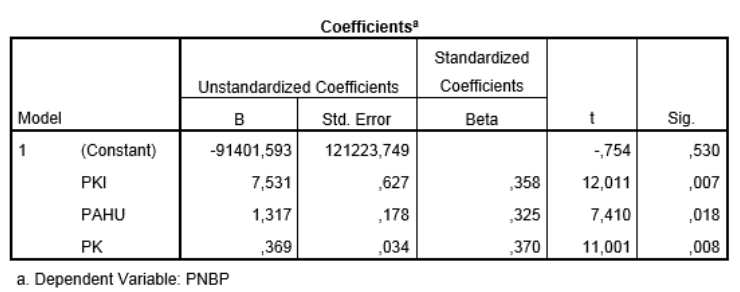

Dari hasil output SPSS tersebut diatas maka dapat disusun persamaan regresi linier berganda sebagai berikut:

Penerimaan Negara Bukan Pajak $=-91401,593+$ 7,531 Penerimaan Kekayaan Intelektual $+1,317$ Penerimaan Administrasi Hukum Umum + 0,369 Penerimaan Keimigrasian.

Dari hasil persamaan regresi linier berganda tersebut di atas maka dapat dianalisis sebagai berikut :

1. Nilai konstanta sebesar $-91401,593$ menyatakan bahwa jika nilai dari variabelvariabel independen (Penerimaan Kekayaan Intelektual, Penerimaan Administrasi Hukum Umum, Penerimaan Keimigrasian) adalah 0 (nol), maka besarnya PNBP adalah sebesar 91401,593.

2. Variabel Penerimaan Kekayaan Intelektual. Dari perhitungan persamaan regresi linier berganda, hasilnya adalah nilai koefisien variabel Penerimaan Kekayaan Intelektual sebesar 7,531 dan nilai signifikan lebih kecil dari 0,05 yaitu sebesar 0,007 maka hipotesis 1 diterima. Ini berarti bahwa variabel Penerimaan Kekayaan Intelektual berpengaruh positif dan signifikan terhadap
PNBP. Tanda positif pada koefisien menunjukkan bahwa meningkatnya nilai Penerimaan Kekayaan Intelektual pada umumnya akan meningkatkan PNBP. Berarti bahwa setiap peningkatan rasio Penerimaan Kekayaan Intelektual sebesar 1\% maka akan mengakibatkan kenaikan PNBP Kementerian Hukum dan HAM RI sebesar 7,531\%.

3. Variabel Penerimaan Administrasi Hukum Umum. Dari perhitungan persamaan regresi linier berganda, hasilnya adalah nilai koefisien variabel Penerimaan Administrasi Hukum Umum sebesar 1,317. dan nilai signifikan lebih kecil dari 0,05 yaitu sebesar 0,018 maka hipotesis 2 diterima. Ini berarti bahwa variabel Penerimaan Administrasi Hukum Umum berpengaruh positif dan signifikan terhadap PNBP. Tanda positif pada koefisien menunjukkan bahwa meningkatnya nilai Penerimaan Administrasi Hukum Umum pada umumnya akan meningkatkan PNBP. Berarti bahwa setiap peningkatan Penerimaan Administrasi Hukum Umum sebesar $1 \%$ maka akan mengakibatkan kenaikan PNBP perusahaan sebesar 1,317\%.

4. Variabel Penerimaan Keimigrasian.

Dari perhitungan persamaan regresi linier berganda, hasilnya adalah nilai koefisien variabel Penerimaan Keimigrasian sebesar 0,369. dan nilai signifikan lebih kecil dari 0,05 yaitu sebesar 0,008 maka hipotesis 3 diterima. Ini berarti bahwa variabel Penerimaan Keimigrasian berpengaruh positif dan signifikan terhadap PNBP. Tanda positif pada koefisien menunjukkan bahwa meningkatnya nilai Penerimaan Keimigrasian pada umumnya akan meningkatkan PNBP. Berarti bahwa setiap peningkatan Penerimaan Keimigrasian sebesar 1\% maka akan mengakibatkan kenaikan PNBP perusahaan sebesar 0,369\%.

Berdasarkan hasil pengujian uji $t$, Penerimaan Kekayaan Intelektual menunjukkan secara parsial berpengaruh positif dan signifikan terhadap Penerimaan Negara Bukan Pajak pada Kementerian Hukum dan HAM RI, dimana hasilnya adalah nilai koefisien variabel Penerimaan Kekayaan Intelektual sebesar 7,531 dan nilai signifikan lebih kecil dari 0,05 yaitu sebesar 0,007 maka hipotesis 1 diterima. Ini 
berarti bahwa variabel Penerimaan Kekayaan Intelektual berpengaruh positif dan signifikan terhadap PNBP. Tanda positif pada koefisien menunjukkan bahwa meningkatnya nilai Penerimaan Kekayaan Intelektual pada umumnya akan meningkatkan PNBP. Berarti bahwa setiap peningkatan rasio Penerimaan Kekayaan Intelektual sebesar 1\% maka akan mengakibatkan kenaikan PNBP Kementerian Hukum dan HAM RI sebesar 7,531\%.

Berdasarkan hasil pengujian uji $\mathrm{t}$, Penerimaan Administrasi Hukum Umum menunjukkan secara parsial berpengaruh positif dan signifikan terhadap Penerimaan Negara Bukan Pajak pada Kementerian Hukum dan HAM RI, dimana hasilnya nilai koefisien variabel Penerimaan Administrasi Hukum Umum adalah nilai koefisien variabel Penerimaan Administrasi Hukum Umum sebesar 1,317. dan nilai signifikan lebih kecil dari 0,05 yaitu sebesar 0,018 maka hipotesis 2 diterima. Ini berarti bahwa variabel Penerimaan Administrasi Hukum Umum berpengaruh positif dan signifikan terhadap PNBP. Tanda positif pada koefisien menunjukkan bahwa meningkatnya nilai Penerimaan Administrasi Hukum Umum pada umumnya akan meningkatkan PNBP. Berarti bahwa setiap peningkatan Penerimaan Administrasi Hukum Umum sebesar 1\% maka akan mengakibatkan kenaikan PNBP perusahaan sebesar 1,317\%.

Berdasarkan hasil pengujian uji $t$, Penerimaan Keimigrasian menunjukkan secara parsial berpengaruh positif dan signifikan terhadap Penerimaan Negara Bukan Pajak pada Kementerian Hukum dan HAM RI, dimana hasilnya adalah nilai koefisien variabel Penerimaan Keimigrasian sebesar 0,369 dan nilai signifikan lebih kecil dari 0,05 yaitu sebesar 0,008 maka hipotesis 3 diterima. Ini berarti bahwa variabel Penerimaan Keimigrasian berpengaruh positif dan signifikan terhadap PNBP. Tanda positif pada koefisien menunjukkan bahwa meningkatnya nilai Penerimaan Keimigrasian pada umumnya akan meningkatkan PNBP. Berarti bahwa setiap peningkatan Penerimaan Keimigrasian sebesar 1\% maka akan mengakibatkan kenaikan PNBP perusahaan sebesar $0,369 \%$.
Dari hasil analisis regresi linear berganda (Penerimaan Negara Bukan Pajak $=-91401,593$ + 7,531 Penerimaan Kekayaan Intelektual + 1,317 Penerimaan Administrasi Hukum Umum + 0,369 Penerimaan Keimigrasian) menunjukkan bahwa Penerimaan Kekayaan Intelektual berpengaruh signifikan paling dominan terhadap Penerimaan Negara Bukan Pajak. Dimana Koefisien Penerimaan Kekayaan Intelektual sebesar 7,531, Berarti bahwa setiap peningkatan Penerimaan Kekayaan Intelektual sebesar 1\% maka akan mengakibatkan kenaikan Penerimaan Kekayaan Intelektual sebesar 7,531\%. sedangkan koefisien Penerimaan Administrasi Hukum Umum hanya sebesar 1,317, yang berarti jika setiap peningkatan Penerimaan Administrasi Hukum sebesar 1\% maka akan mengakibatkan kenaikan PNBP perusahaan sebesar 1,317\%. Dan yang paling kecil berdasarkan hasil SPSS yaitu Penerimaan Keimigrasian yang berarti bahwa setiap peningkatan Penerimaan Keimigrasian sebesar 1\% maka akan mengakibatkan kenaikan PNBP perusahaan sebesar 0,369\%.

Berdasarkan hasil pengujian uji $\mathrm{f}$, variabel variabel Penerimaan Kekayaan Intelektual, Penerimaan Administrasi Hukum Umum dan Penerimaan Keimigrasian secara bersama-sama berpengaruh signifikan terhadap Penerimaan Negara Bukan Pajak pada Kementerian Hukum dan HAM RI, karena nilai signifikanya sebesar 0,001 lebih kecil dari 0,05.

\section{KESIMPULAN}

Berdasarkan analisis data dan pembahasan serta dari hipotesis yang telah disusun dan telah diuji pada bab sebelumnya, maka dapat disimpulkan pengaruh variabelvariabel independen terhadap Penerimaan Negara Bukan Pajak (PNBP) sebagai berikut. Berdasarkan hasil pengujian uji t, Penerimaan Kekayaan Intelektual menunjukkan secara parsial berpengaruh positif dan signifikan terhadap Penerimaan Negara Bukan Pajak pada Kementerian Hukum dan HAM RI, dimana hasilnya adalah nilai koefisien variabel Penerimaan Kekayaan Intelektual sebesar 7,531 dan nilai signifikan lebih kecil dari 0,05 yaitu 
sebesar 0,007 maka hipotesis 1 diterima. Ini berarti bahwa variabel Penerimaan Kekayaan Intelektual berpengaruh positif dan signifikan terhadap PNBP. Berdasarkan hasil pengujian uji t, Penerimaan Administrasi Hukum Umum menunjukkan secara parsial berpengaruh positif dan signifikan terhadap Penerimaan Negara Bukan Pajak pada Kementerian Hukum dan HAM RI, dimana hasilnya nilai koefisien variabel Penerimaan Administrasi Hukum Umum adalah nilai koefisien variabel Penerimaan Administrasi Hukum Umum sebesar 1,317. dan nilai signifikan lebih kecil dari 0,05 yaitu sebesar 0,018 maka hipotesis 2 diterima. Ini berarti bahwa variabel Penerimaan Administrasi Hukum Umum berpengaruh positif dan signifikan terhadap PNBP.

Berdasarkan hasil pengujian uji $t$, Penerimaan Keimigrasian menunjukkan secara parsial berpengaruh positif dan signifikan terhadap Penerimaan Negara Bukan Pajak pada Kementerian Hukum dan HAM RI, dimana hasilnya adalah nilai koefisien variabel Penerimaan Keimigrasian sebesar 0,369 dan nilai signifikan lebih kecil dari 0,05 yaitu sebesar 0,008 maka hipotesis 3 diterima. Ini berarti bahwa variabel Penerimaan Keimigrasian berpengaruh positif dan signifikan terhadap PNBP.

\section{SARAN}

Setelah mengkaji hasil penelitian ini maka saran yang dapat penulis ajukan sebagai berikut. Untuk Kementerian Hukum dan HAM RI, agar lebih memperhatikan faktor penerimaan Kekayaan negara bukan pajak yang diteliti dalam penelitian ini yaitu Penerimaan keimigrasian, Penerimaan Kekayaan Intelektual, dan Penerimaan Administrasi Hukum Umum yang memiliki pengaruh yang positif terhadap PNBP di Kementerian Hukum dan HAM RI. Dalam penelitian ini, Penerimaan Kekayaan Intelektual merupakan penerimaan yang paling dominan mempengaruhi PNBP di Kementerian Hukum dan HAM RI sehingga Penerimaan Kekayaan Inteletktual yang baik ini harus tetap dipertahankan oleh Kementerian Hukum dan HAM RI dan tentunya harus lebih di tingkatkan dari masa ke masa.
Untuk selanjutnya diharapkan dapat mengembangkan penelitian ini dengan menambahkan variabel - variabel lainnya yang dapat digunakan untuk memprediksi penerimaan lainnya yang berpengaruh signifikan terhadap PNBP di Kementerian Hukum dan HAM RI.

\section{Daftar Pustaka}

Adrian Sutedi, 2005,Hukum Pajak, Penerbit : Sinar Grafika, Jakarta.

Ahmadi Miru, 2005, Hukum Merek, Penerbit : Rajagrafindo Persada, Jakarta.

Bagir Manan, "Hukum Keimigrasian dalam Sistem Hukum Nasional", disampaikan dalam Rapat Kerja Nasional Keimigrasian.

Bernard Nainggolan, 2011, Pemberdayaan Hukum Hak Cipta dan Lembaga Manajemen Kolektif, Penerbit : P.T. Alumni, Bandung.

David Sukardi Kodrat dan Christian Herdinata, 2009, Managemen Keuangan Based On Empirical Research Edisi ke- 1, Penerbit : Graha Ilmu, Yogyakarta

Eddy Sadeli, 2007, Kewarganegaraan Republik Indonesia Cetakan Ke- 2, Penerbit : Lembaga Penelitian dan Pengabdian Masyarakat Tionghoa Indonesia, Jakarta

Eugene F. Bringham and Michael C. Ehrhardt, 2014, Financial Management Theory and Practice, South-Western Cengange Learning, USA.

Eugene F. Bringham, Joel F. Houston, 2006, Fundamental of Financial Management, Edisi ke-10 Buku 1, Penerbit : Salemba Empat, Jakarta.

Endang Winarsih sriyanto, Achmad Choiruman Mudi Cahyono, Nova Perwira Yudha, Kurniasih Tri Buana, 2011, Pratikum Managemen Keuangan, Penerbit : Salemba Empat, Jakarta.

Fred R, David, 2011, Manajemen Strategi Konsep, Edisi ke-12 Buku 1, Penerbit : Salemba Empat, Jakarta.

Hendar Kusnadi, 2005, Ekonomi Koperasi, Penerbit : Fakultas Ekonomi Universitas Indonesia, Jakarta.

Henry Soelistyo, 2011, Hak Cipta Tanpa Hak Moral, Penerbit : Rajawali Pers, Jakarta. 
H. Ok. Saidin, 2013, Aspek Hukum Kekayaan Intelektual Cetakan ke-8, Penerbit : P.T. Raja Grafindo Persada, Jakarta.

Imam Ghozali, 2011, Aplikasi Analisis Multivariate dengan Program IBM SPSS 19 : Badan Penerbit Univeritas Diponogoro, Semarang.

Irham Fahmi, 2012, Analisis Kinerja Keuangan, Penerbit : Alfabeta, Bandung.

Irham Fahmi, 2012, Pengantar Manajemen Keuangan, Penerbit : Alfabeta, Bandung.

Jae K. Shim, Joel G. Siegel, 2008, Financial Management, Barron Education Series Inc, New York.

James C. Van Home, John M. Wachowicz, 2005, Fundanmental of Financial Management, Edisi ke-12 Buku 1, Penerbit : Salemba Empat, Jakarta.

Kasmir, 2013, Analisis Laporan Keuangan, Penerbit : Rajagrafindo Persada, Depok.

Leny Sulistyowati, 2010, Panduan Praktis Memahami Laporan Keuangan, Penerbit : Elex Media Komutindi, Jakarta.

Muhammad Djafar Saidi, 2008, Hukum Penerimaan Negara : P.T. Raja Grafindo Persada, Jakarta.

Muhammad Djafar Saidi, 2011, Hukum Keuangan Negara Cetakan ke-2, Penerbit : P.T. Raja Grafindo Persada, Jakarta.

Muhammad Djafar Saidi, 2008, Hukum Penerimaan Negara Bukan Pajak, Penerbit : PT Raja Grafindo Persada, Jakarta.

M. Hawin. 2010, Intellectual Property Law On Parallel Important, Penerbit : Universitas Gajah Mada, Yogyakarta.

M. Yahya Harahap, 2013, Hukum Perseroan Terbatas, Penerbit : Sinar Grafika, Jakarta.

M. Iman Santoso,2005, Lintas Sejarah Imigrasi Indonesia, Penerbit : Ditjen Imigrasi, Jakarta

Peddina Mohana Rao, 2011, Financial Analaisis and Reporting, PHI Learning Private Limited, New Delhi.

Pipin Syarifin, Dra. Dedeh Jubaedah, 2012, Hukum Dagang Indonesia,Cetakan ke-1 Penerbit : CV Pustaka Setia, Bandung.

Riduwan, 2013, Metode dan Teknik Menyusun Tesis Cetakan-9 : Peneribit Alafbeta Bandung.
Rudi Prasetya, 2012, Yayasan Dalam Teori dan Praktek, Penerbit : Sinar Grafika, Jakarta.

Saidin, OK, Aspek Hukum Hak Kekayaan Intelektual, Jakarta : PT Raja Grafindo Persada.

Setyawati, I. R. M. A., Kartini, D., Rachman, S., \& Febrian, E. (2015). Assessing the Islamic banking financial performance in Indonesia. International Journal of Education and Research, 3(10), 233-248.

Setyawati, Irma. "Determinants of Growth and Profitability by Bank Specific Variable and Market Stucture in Islamic Banking in Indonesia." Academy of Strategic Management Journal 15 (2016): 1-14.

Sutiksno, Dian Utami, Ansari Saleh Ahmar, Universitas Negeri Makasar, Indonesia Irma Setyawati, Indonesia Muh Yamin Noch, and Victor Pattiasina. "MARKET ORIENTATION AND DISTINCTIVE COMPETENCE TOWARD SERVICE MIX ON STUDY PROGRAMS OF HIGHER EDUCATION IN MALUKU, INDONESIA." Journal of Entrepreneurship Education 22, no. 1 (2019).

Sutrisno, 2013, Manajemen Keuangan Teori Konsep dan Aplikasi, Edisi ke-1 Cetakan ke-9, Ekonisia, Yogyakarta.

Suyud Margono, 2011, Hak Milik Industri, Penerbit : Ghalia Indonesia, Bogor.

Suyud Margono, 2010, Hukum Hak Cipta Indonesia, Penerbit : Ghalia Indonesia, Bogor.

Syahmin AK, 2007, Hukum Dagang Internasional Dalam Kerangka Studi Analitis, P.T. Raja Grafindo Persada Indonesia, Jakarta.

Syofyan, Almaghfirah. 2013. Ilmu Administrasi Fiskal. Evaluasi Kebijakan Tarif dan Jenis Penerimaan Negara Bukan Pajak Sektor Perikanan. Depok: FISIP UI.

S. Munawir, 2007, Analisis Laporan Keuangan, Edisi ke-4 Cetakan ke-14, Penerbit : Liberty, Yogyakarta.

Tulus Tambunan, 2012, Perekonomian Indonesia, Kajian Teoritis dan Analisis dan Empiris, Cetakan ke-1, Penerbit : Ghalia Indonesia, Bogor.

Yuliyanti, Eli dan Nila Aprilla. 2014. Analisis Efektivitas dan Kontribusi Pendapatan 
Negara Bukan Pajak (PNBP) pada Fakultas di Universitas Bengkulu. Bengkulu: Fakultas Ekonomi dan Bisnis Universitas Bengkulu.

Yusup, Rifai. 2011. Hukum Keuangan Negara. Pengaturan dan Pengelolaan Penerimaan Negara Bukan Pajak dari Kegiatan Pelayanan Pertanahan oleh Badan Pertanahan Nasional. Depok: Fakultas Hukum Universitas Indonesia.

V Rajasekaran, 2012, Acounting For Manager, Dorling Kindersley (India) Pvt, Ltd.

Vyuptakesh Sharan, 2009, Fundamental of Financial Management, Dorling Kindersley (India) Pvt, Ltd.

Undang - Undang Nomor 20 Tahun 1997 Tentang Penerimaan Negara Bukan Pajak

Undang - Undang Nomor 14 Tahun 2001 Tentang Hak Paten

Undang - Undang Nomor 19 Tahun 2002 Tentang Hak Cipta

Undang - Undang 15 Tahun 2001 Tentang Merek

Undang - Undang Nomor 29 Tahun 2000 Tentang Perlindungan Varietas Baru Tanaman

Undang - Undang Nomor 30 Tahun 2000 Tentang Desain Industri

Undang - Undang Nomor 32 Tahun 2000 Tentang Desain Tata Letak Sirkuit Terpadu

Peraturan Pemerintah Nomor 22 Tahun 1997 tentang Jenis dan Penyetoran Penerimaan Negara Bukan Pajak

Peraturan Pemerintah Nomor 73 Tahun 1999 tentang Tata Cara Penggunaan Penerimaan Negara Bukan Pajak Yang Bersumber dari Kegiatan Tertentu

Peraturan Pemerintah Nomor 1 Tahun 2004 tentang Tata Cara Penyampaian Rencana dan Laporan Realisasi Penerimaan Negara Bukan Pajak.

Peraturan Pemerintah Nomor 22 Tahun 2005 tentang Pemeriksaan PNBP.

Peraturan Pemerintah Nomor 29 Tahun 2009 tentang Tata Cara Penentuan Jumlah dan Penyetoran PNBP yang Terutang

Peraturan Pemerintah Nomor 45 Tahun 2014 tentang Jenis dan Tarif atas Jenis Penerimaan Negara Bukan Pajak pada
Kementerian Hukum dan Hak Asasi Manusia.

Peraturan Pemerintah Nomor 38 Tahun 2009 tentang Tarif atas Jenis Penerimaan Negara Bukan Pajak.

Keputusan Presiden Nomor 15 tahun 1997 perubahan keputusan presiden nomor 24 tahun 1979 pengesahan paris convention for the protection of industrial property dan convention establishing the world intellectual property organization

Keputusan Presiden Nomor 16 Tahun 1997 Ratifikasi Patent Cooperation Treaty (PCT)

Keputusan Presiden Nomor 17 Tahun 1997 ratifikasi Trade Mark Law Treaty

Keputusan Presiden Nomor 18 Tahun 1997 Ratifikasi Konvensi Bern

Keputusan Presiden Nomor 19 Tahun 1997 Ratifikasi World Intellectual Property Orgnization (WIPO) Copyrights Treaty

Laporan Tahunan Direktorat Jenderal Administrasi Hukum Umum Tahun 2014, Jakarta : Direktorat Jenderal Administrasi Hukum Umum Kementerian Hukum dan HAM RI

Laporan Tahunan Direktorat Jenderal Imigrasi 2013, Jakarta : Direktorat Imigrasi Kementerian Hukum dan HAM RI

Laporan Keuangan Kementerian Hukum dan HAM RI T.A. 2014 UNAUDITED : Sekretariat Jenderal Kementerian Hukum dan HAM RI 